\title{
Biochar development from thermal TGA studies of individual food waste vegetables and their blended systems
}

\author{
Samar Elkhalifa ${ }^{1}$ Prakash Parthasarathy ${ }^{1}$ (D) Hamish R. Mackey ${ }^{1} \cdot$ Tareq Al-Ansari $^{1,2} \cdot$ Omar Elhassan $^{3}$. \\ Said Mansour ${ }^{3} \cdot$ Gordon McKay $^{1}$
}

Received: 24 October 2021 / Revised: 19 January 2022 / Accepted: 3 February 2022

(c) The Author(s) 2022

\begin{abstract}
The amount of food waste that is generated all over the world is enormous. As food wastes are rich in nutrients and organics, they serve as a potential source for the generation of many value-added commodities and energy. In most countries, food wastes are predominately dumped in open lands or incinerated, along with other combustible materials such as municipal solid wastes, for the possible extraction of energy. However, these two modes of food wastes disposal are encountering more and more environmental, technical, and economical challenges. More recently, it has been realized that food wastes can be transformed into energy and value-added products, such as horticultural biochars, using thermochemical technologies such as pyrolysis and gasification. In the current research work, three selected food items, carrots, cucumbers, and tomatoes, have been studied using thermogravimetric analysis. The biochar analysis involves one single food item (carrot), one binary mixture (carrot + cucumber), and one ternary blend of carrot, cucumber, and tomato. Two heating rates were used in order to perform kinetic modeling studies using the Arrhenius and Coats-Redfern models. Since the production of the pyrolysis gases-for energy and chemicals production - is of major economic significance regarding the overall process viability, the TGA syngas for a single component, binary component and tertiary component systems were analyzed by TGA coupled mass spectrometry. The results of the gas analysis indicate an increase in hydrogen generation due to blending the food wastes.
\end{abstract}

Keywords Pyrolysis · Vegetable waste foodstuffs $\cdot$ Biochar $\cdot$ Single and multi-components $\cdot$ Kinetics $\cdot$ TGA-MS

\section{Introduction}

Solid wastes are generated enormously around the globe because of the fast-paced rates of urbanization and industrialization. Several factors contribute to the concern over the proper management of these wastes, including a limited number of landfills, environmental challenges, and public

Prakash Parthasarathy

prakrock@gmail.com

$\bowtie$ Gordon McKay gmckay@hbku.edu.qa

1 Divison of Sustainable Development, College of Science and Engineering, Hamad Bin Khalifa University, Qatar Foundation, Doha, Qatar

2 Division of Engineering Management and Decision Sciences, College of Science and Engineering, Hamad Bin Khalifa University, Doha, Qatar

3 Core Labs, Qatar Environment and Energy Research Institute, Hamad Bin Khalifa University, Doha, Qatar awareness. People are consuming more and generating vast quantities of waste to achieve increasing living standards, while industries are booming to meet such demands. Consequently, these unsustainable patterns place pressure on the environment, which is already suffering, and serious action must be taken to reverse the damage and save the planet for future generations.

The use of thermochemical conversion techniques in converting waste to energy is gaining wide acceptance due to the many benefits resulting from the conversion of waste into energy, fuel, and other products [1-3]. In particular, biomass waste constitutes a source of energy that is both cheap and abundant [4]. Therefore, biomass conversion into energy requires a lot more attention. There are many routes that can be followed to achieve the benefits of waste to energy conversion. Pyrolysis, for instance, is a promising technique that needs more research in order to be commercialized and used on a larger scale [5]. This will enable concepts like sustainability and the circular economy to be employed and utilized more efficiently worldwide. 
Biochar is a charcoal-like material that is full of benefits and is the result of the conversion of waste to products through the pyrolysis process [6]. Some of the applications of biochar include its use in agriculture in order to increase water retention and fertility of lands and soils, in addition to its use as a precursor for adsorbents like those used in water treatment [7]. The addition of biochar to the soil can reduce denitrification, thus resulting in less $\mathrm{N}_{2} \mathrm{O}$ emissions [8]; furthermore, several researchers have reported that adding biochar to the soil can boost crop yields by improving soil cation exchange capacity, water retention capacity, nutrient retention capability, improving soil fertility, and enhancing soil microbial activity, and $\mathrm{pH}$ [9-11]. Hence, it is important to understand the processes used to produce such biochars and other products. This can be achieved by the application of thermogravimetric analysis (TGA). The application of TGA involves studying changes in materials and products by following patterns related to change in weight loss with respect to temperature and time.

Globally, tomato is the second most used vegetable after potato, while carrot and cucumber are among the top ten most consumed vegetables. According to FAOSTAT, about 182 million tonnes of tomato, nearly 75 million tonnes of cucumber and gherkin, and almost 40 million tonnes of carrot and turnip are produced worldwide [12]. Due to the massive consumption of carrots, cucumbers, and tomatoes worldwide, huge quantities of these vegetable waste materials are produced every year. Despite having a high moisture content, the above vegetables have a high volatile content, which makes them potentially useful as sources of energy. Hence, in this study, carrot, cucumber, and tomato are considered, and their potential as feedstocks for pyrolysis is investigated. Many researchers have used TGA to investigate the pyrolytic conversion of biomass waste and food waste [13-15]. Specific examples of biomass waste and food waste included bamboo cane [16], camel manure [17], sewage sludge [18], and fruit waste [19]. The vast quantities of food waste generated are a strong motivation to use them in waste to energy conversion owing to their unique properties. This is especially true if methods like pyrolysis are used to transform them $[20,21]$.

The thermal characteristics and pyrolysis behavior of many vegetable wastes have been investigated by researchers. Table 1 presents excerpts of previous studies on pyrolysis characteristics of some top consumed vegetable wastes.

The table indicates that studies on thermal behavior and pyrolytic characteristics of some widely consumed vegetables such as tomato, cucumber, and carrot are yet to be made. Hence, in this study, the characteristics of pyrolytic decomposition of tomato, cucumber, and carrot wastes using TGA have been investigated. The study also investigates the pyrolytic response of the vegetable wastes' binary (tomato + cucumber, tomato + carrot, and cucumber + carrot) and ternary (tomato + cucumber + carrot) blends which are quite novel. To produce value-added products from lignocellulosic biomass through pyrolysis, large amounts of feedstock would be required, which means blended biomass - rather than a single type of biomass - would be required. In addition, feedstock blending has a significant impact on the distribution of pyrolysis products. The pyrolytic degradation kinetics of all combinations (individual vegetable wastes, binary, and ternary vegetable blends) are determined employing two singleheating rate models such as Arrhenius and Coat-Redfern (CR). The information on the thermal characteristics and pyrolytic decomposition kinetics will be helpful in the design of pyrolyzer systems and in the calculation of the heat and mass balance of the process.

\section{Materials and methodology}

The three vegetable materials investigated in this study are carrots (Daucus carota subsp. Sativus), cucumbers (Cucumis sativus), and tomatoes (Solanum lycopersicum). These raw materials have been studied as a single-component system (carrot), binary component system (carrots + cucumbers), and the ternary component system (carrots + cucumbers + tomatoes). Prior to the TGA, the binary and ternary mixtures of components were prepared and mixed in an equal proportion by weight. This enabled the study of the different interactions between the components.

Initially, the raw materials (i.e., cucumbers, carrots, and tomatoes) were first dried using a hot-air oven at a temperature of $140{ }^{\circ} \mathrm{C}$ for $24 \mathrm{~h}$. Next, the dried sample was chopped into smaller chunks, which was followed by grinding them into finer particles as required for TGA. The TGA was carried out from room temperature to $800{ }^{\circ} \mathrm{C}$ at two different heating rates, namely 5 and $10{ }^{\circ} \mathrm{C} / \mathrm{min}$ under an $\mathrm{N}_{2}$ atmosphere $(100 \mathrm{ml} / \mathrm{min})$ employing the thermogravimetric analyzer (Discovery TGA 550, TA Instruments). As the purpose of the study is to produce biochar, the TGA experiments were performed at slow heating rates (5 and $10{ }^{\circ} \mathrm{C} / \mathrm{min}$ ). Additionally, slow heating results in effective heat transfer between particles, resulting in effective cracking/decomposition of particles. Approximately $7-18 \mathrm{mg}$ of the raw materials was used for the thermogravimetric weight-change analysis. TGA was conducted by ramping the temperature up from room temperature to $100{ }^{\circ} \mathrm{C}$ using two different heating rates of 5 and $10{ }^{\circ} \mathrm{C} /$ min; keeping an isothermal condition at $100{ }^{\circ} \mathrm{C}$ for $10 \mathrm{~min}$; ramping the temperature up to $800{ }^{\circ} \mathrm{C}$ using two different heating rates of 5 and $10{ }^{\circ} \mathrm{C} / \mathrm{min}$. Furthermore, the evolving gases were monitored using a mass spectrometer coupled to the thermogravimetric analyzer. 


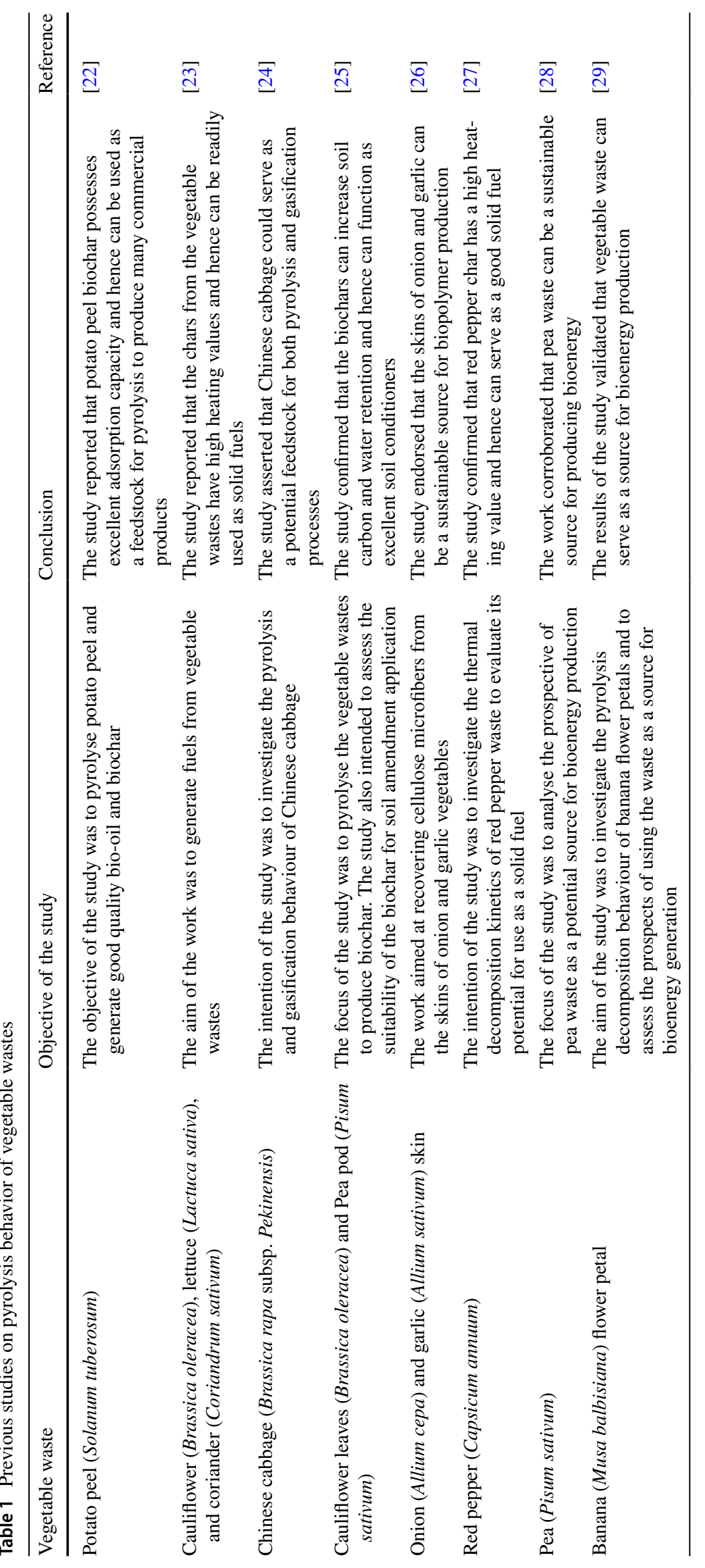




\subsection{Materials characterisation}

The materials analysis methods used to characterize these raw materials are:- proximate analysis on a wet and dry basis, for volatile content, fixed carbon, and ash content; elemental or ultimate analysis on a dry and ash-free basis for carbon, hydrogen, sulfur, nitrogen, and oxygen by difference. The standard followed for the determination of moisture content was a procedure by Choi et al. [30]. The instrument used for the proximate analysis was a SDT 650 (TA Instruments) Thermal analyzer, and the standard used for the proximate analysis was ASTM D7582-12. The elemental analysis of the feedstocks was carried out using a Euro-vector Euro EA $3000 \mathrm{CHN}$ elemental analyzer. The ultimate analysis was conducted in line with standard ASTM D 3176-8.

\subsection{Kinetic analysis models}

For the purpose of pyrolyzer design, a detailed understanding of the pyrolysis-activation mechanism is essential. The TGA technique enables the study of the pyrolysis and activation behaviors of biomass materials. The formation of char from biomass consists of pyrolysis under an inert gas atmosphere to disintegrate the cross-linkage between carbon atoms. Although various kinetic models have been established for the study of pyrolysis mechanisms and kinetic parameters using TGA [31-39], in the present study, the Arrhenius and CR kinetic models were employed. The Arrhenius model is used because it is simple and assists in determining the order of reaction as such. In addition, the model had been used to determine the slow pyrolysis kinetics of lignocellulosic biomass such as sugarcane bagasse, coconut, coir pith, groundnut shell, casuarina leaves [40], sawdust, rice husk, and wheat husk, [41]. The CR model, like the Arrhenius model, does not require more than one heating rate to calculate kinetics and is used in this study because of its simplicity. The model was selected for its success in determining the slow pyrolysis kinetics of biomasses such as pine sawdust, olive waste, date palm trunk, seaweed [42], hemicellulose of Camellia Oleifera shell [43], and dry kitchen wastes [44].

\subsubsection{Arrhenius model}

The theoretical background of the model is presented below:

The kinetics of the devolatilization (pyrolysis) process can be given by

$\frac{-d X}{d t}=k X^{n}$

where $X$ represents weight fraction undergoing decomposition, $k$ corresponds to the reaction constant, and $n$ is the order of the reaction.
The $X$ and $k$ can be presented as below:

$X=\frac{w-w_{f}}{w_{0}-w_{f}}$

where $w_{0}$ is the initial weight of the sample before pyrolysis decomposition, $w$ is the weight of the sample at a particular time, while $w_{f}$ is the final weight of the sample after pyrolysis decomposition.

$k=A e^{-R T}$

where $R$ is the universal gas constant $\left(8.314 \mathrm{~J} \mathrm{~mol}^{-1} \mathrm{~K}^{-1}\right)$ and $T$ is the absolute temperature (K).

Substituting the values of $X$ and $k$ in Eq. (1) gives the below equation:

$\ln \left[\frac{-1}{w_{0}-w_{f}} \frac{d w}{d t}\right]=\ln (A)-\left[\frac{E}{R T}\right]+n \ln \left[\frac{w-w_{f}}{w_{0}-w_{f}}\right]$

where $\frac{d w}{d t}$ is the rate of change in weight of the sample undergoing degradation?

Equation (4) takes the below form:

$y=B+C x+D z$

where $y$ resembles $\ln \left[\frac{-1}{w_{0}-w_{f}} \frac{d w}{d t}\right], x$ resembles $\frac{1}{T}$, and $z$ resembles $\ln \left[\frac{w-w_{f}}{w_{0}-w_{f}}\right]$.

While the constant $B$ and coefficients of $C$ and $D$ correspond to

$B=\ln (A), C=\left[\frac{-E}{R}\right], D=n$

\subsubsection{Coats-Redfern model (CR)}

In general, the $\mathrm{CR}$ model is given by

$\ln \left[\frac{g(\propto)}{T^{2}}\right]=\ln \left[\frac{A R}{\beta E}\right]-\frac{E}{R T}$

While the reaction mechanisms of the CR model can be broadly classified into (i) based on the rate-determining reactions; (ii) based on reactions influenced by the diffusion of solids; (iii) based on the interphase transfer of products [44]. A few most common reaction equations and the functions of $g(\propto)$ in the CR model are presented in Table 2.

\subsection{TGA-MS analysis}

The TGA-MS analysis provides information on the thermal behavior of feedstocks as well as details on the distribution of products. A mass spectrometer (MS) makes use of differences in the mass-to-charge ratio of ionized molecules to identify species or components, and those mass-to-charge ratios are 
Table 2 Reaction models of the CR model

\begin{tabular}{|c|c|c|c|c|}
\hline Reaction mechanism & Reaction model & Abbreviation & Integral form of the model $g(\propto)$ & Equation \\
\hline \multirow[t]{3}{*}{ Based on rate determining reactions } & One nucleus on the individual particle & $\mathrm{F}_{1}$ & $-\ln (1-\propto)$ & (8) \\
\hline & Two nuclei on the individual particle & $\mathrm{F}_{2}$ & $(1-\propto)^{-1}-1$ & (9) \\
\hline & Three nuclei on the individual particle & $\mathrm{F}_{3}$ & {$\left[(1-\propto)^{-2}-1\right] / 2$} & $(10)$ \\
\hline \multirow{4}{*}{$\begin{array}{l}\text { Based on reactions controlled by diffu- } \\
\text { sion of solids }\end{array}$} & One-dimensional diffusion & $\mathrm{D}_{1}$ & $\alpha^{2}$ & $(11)$ \\
\hline & $\begin{array}{l}\text { Two-dimensional diffusion (Valensi } \\
\text { model) }\end{array}$ & $\mathrm{D}_{2}$ & $(1-\propto) \ln (1-\propto)+\propto$ & (12) \\
\hline & $\begin{array}{l}\text { Three-dimensional diffusion (Jander } \\
\text { model model) }\end{array}$ & $\mathrm{D}_{3}$ & $1-(1-\propto)^{1 / 3^{2}}$ & (13) \\
\hline & $\begin{array}{l}\text { Three-dimensional diffusion (Ginstlinge- } \\
\text { Brounshtein model) }\end{array}$ & $\mathrm{D}_{4}$ & {$\left[1-\left(\frac{2}{3}\right) \propto\right]-(1-\propto)^{2 / 3}$} & $(14)$ \\
\hline \multirow{2}{*}{$\begin{array}{l}\text { Based on the interphase transfer of } \\
\text { products }\end{array}$} & Contracting area & $\mathrm{R}_{2}$ & $1-(1-\propto)^{1 / 2}$ & $(15)$ \\
\hline & Contracting volume & $\mathrm{R}_{3}$ & $1-(1-\propto)^{1 / 3}$ & (16) \\
\hline
\end{tabular}

referred from the National Institute of Standards and Technology (NIST) database. Since it is unviable to detect all gas components in the syngas, only the $\mathrm{H}_{2}, \mathrm{CH}_{4}, \mathrm{H}_{2} \mathrm{O}$, and $\mathrm{CO}_{2}$ gas components were analyzed, considering the below equation.

Biomass waste $\stackrel{\Delta}{\rightarrow} \mathrm{Char}_{(s)}+\operatorname{Tar}_{(l)}+\mathrm{H}_{2} \mathrm{O}_{(g)}+\mathrm{H}_{2(g)}+\mathrm{CO}_{(g)}+\mathrm{CO}_{2(g)}+\mathrm{CH}_{4(g)}$

The gas components $\mathrm{H}_{2}, \mathrm{CH}_{4}, \mathrm{H}_{2} \mathrm{O}$, and $\mathrm{CO}_{2}$ were analyzed, referring to atomic mass units (amu) $2\left(\mathrm{H}_{2}\right), 15,16$ $\left(\mathrm{CH}_{4}\right), 17,18\left(\mathrm{H}_{2} \mathrm{O}\right)$, and $44\left(\mathrm{CO}_{2}\right)$, respectively. The mass spectra of $\mathrm{N}_{2}, \mathrm{C}_{2} \mathrm{H}_{4}$, and $\mathrm{C}_{2} \mathrm{H}_{6}$ have the same amu 28. Since the TG-MS analysis was conducted under an $\mathrm{N}_{2}$ atmosphere, the data for $\mathrm{C}_{2} \mathrm{H}_{4}$ and $\mathrm{C}_{2} \mathrm{H}_{6}$ was not presented as $\mathrm{N}_{2}$ would have disturbed the amu 28 [45].

\subsubsection{Semi-quantitative gas analysis}

Radojevi'c et al. [45] proposed a new method for estimating the quantity of gas components present in syngas. Based on the method, the volumetric share per unit mass of the gas component is determined using the below equation.

$v_{i}\left[\frac{m^{3}}{k g}\right]=\frac{1}{\beta} \frac{v_{c}}{m} \int_{T 1}^{T 2} \frac{I C_{i}}{I C_{c}} d T$

where $v_{i}$ represents the volumetric share of gas component $\left(\mathrm{m}^{3} \mathrm{~kg}^{-1}\right), \beta$ refers to the heating rate of pyrolysis process $(\mathrm{K} / \mathrm{min}), v_{c}$ corresponds to the volumetric flow rate of carrier gas $(\mathrm{ml} / \mathrm{min}), m$ denotes the mass of the feedstock sample used for the analysis $(\mathrm{mg}), I C_{i}$ refers to the peak ion current of the gas component (A), $I C_{i}$ represents the ion current of the carrier gas (A) (usually the carrier gas has a constant ion current value), $T 1$ and $T 2$ are the lower and upper limits of the integral function, indicating the temperature range used in the calculation. The term $T 1$ is the logarithm of ion current of gas component while $T 2$ is the temperature that corresponds to the peak ion current of the gas component.

\section{Results and discussion}

\subsection{Materials characterization}

Any study of biomass foodstuffs needs to describe the characteristics and properties of the raw materials. When it comes to food waste, an elemental analysis on a dry basis as well as the moisture content is needed. Moisture content becomes critical in thermal treatment studies because it can range from a few percent to over ninety percent, consuming over sixty percent of the heat energy in the thermal processes. The classical analyses for the three vegetables under consideration, namely, carrots, cucumbers, and tomatoes, are now presented.

\subsubsection{Proximate analysis}

Due to the extremely wide range of moisture contents depending on the source and processing methods utilized, the proximate analyses are presented on a dry basis. The moisture contents of the natural vegetables are $90.01 \mathrm{wt}$. $\%, 96.07$ wt. \%, and 94.72 wt. \% for carrots, cucumbers, and tomatoes, respectively. Experiments were performed at least in triplicate to obtain three consistent values that were within $\pm 5 \%$. The results of the proximate analysis of the three vegetable food wastes are presented in Table 3. 
Table 3 Proximate analysis of the chosen vegetables (this study)

\begin{tabular}{llll}
\hline $\begin{array}{l}\text { Vegetable food } \\
\text { wastes }\end{array}$ & \multicolumn{2}{l}{ Components $\left(^{* \mathrm{db}}\right.$ ) } \\
\cline { 2 - 4 } & $\begin{array}{l}\text { Volatile matter } \\
(\text { wt. \%) }\end{array}$ & $\begin{array}{l}\text { Fixed carbon } \\
(\text { wt. \%) }\end{array}$ & $\begin{array}{l}\text { Ash content } \\
\text { (wt. \%) }\end{array}$ \\
\hline Carrot & 85.28 & 9.05 & 5.67 \\
Cucumber & 69.76 & 28.21 & 2.03 \\
Tomato & 80.43 & 14.78 & 4.79 \\
\hline
\end{tabular}

*db, dry basis; ${ }^{* *}$ calculated by difference.

\subsubsection{Ultimate analysis}

The results of the ultimate analysis of the three vegetables are presented in Table 4. The values are based on the average of three measured results for each sample falling within $\pm 6 \%$. The ultimate analysis results of these vegetables reported elsewhere are also presented in the table.

\subsubsection{Heating value}

The higher heating values (HHV) of the foodstuffs is calculated based on the results of the elemental analysis using the correlation proposed by Channiwala and Parikh [49] which is given below:

$H H V\left(\frac{k J}{k g}\right)=349.1 C+1178.3 H+100.5 S+103.4 O-15.1 N-21.1 A s h$

The above correlation is used since the composition of all elements are well within the allowable limits suggested by the researchers, i.e., $C$ : $0-92 \%, H: 0.43-25 \%, N$ : 0-5.6\%, O: 0-50\%, Ash: 0-71\%, HHV: 4745-55,345 kJ/ $\mathrm{kg}$. The obtained heating values of the vegetable wastes are compared with the heating values of other vegetable wastes (cauliflower [23], lettuce [23], coriander [23], banana flower [29], pea [28], potato peel [22]) (see Fig. 1).

It can be noted that the cucumber and tomato wastes have high heating values. The high heating values of the

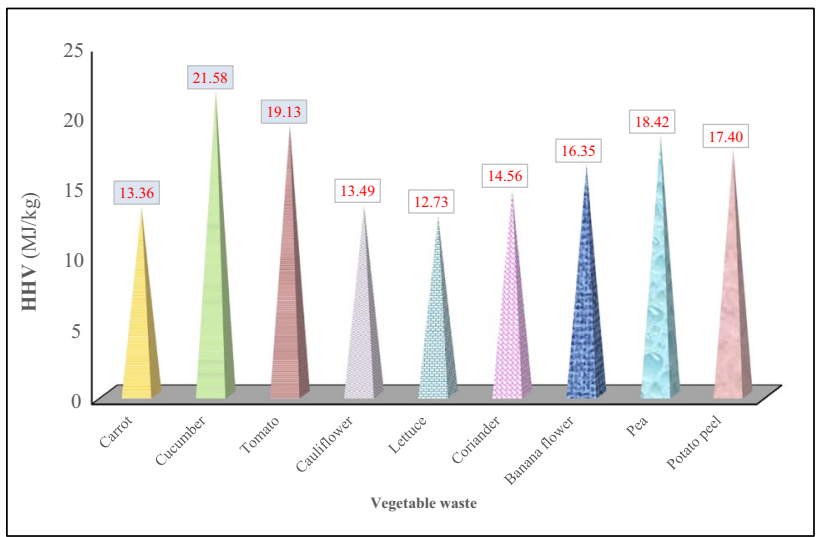

Fig. 1 Heating values of vegetable food wastes

vegetable food wastes are due to their high carbon content and low ash and oxygen content. On the other hand, carrot waste exhibits a low heating value. The low heating value of the waste is because of its low carbon and high oxygen content.

\subsection{TGA profiles and biochar yields}

The TGA profiles at the two heating rates, 5 and $10^{\circ} \mathrm{C} /$ min, are shown in Figs. 2, 3, and 4. The three profiles are for carrots only carrots and cucumbers binary blend and for carrots, cucumber, and tomatoes ternary blend in Figs. 2, 3, and 4, respectively. The TGA data are represented by the dashed lines. The differential thermal gravimetric, DTG, percentage mass losses are shown by the dotted lines and the percentage values on the left-hand scale. The mass quantities at each temperature can be abstracted from the TGA versus temperature curves and are presented in Tables 5 and 6 for the two heating rates at 5 and $10{ }^{\circ} \mathrm{C} / \mathrm{min}$.
Table 4 Elemental analysis results for the food samples dried for $24 \mathrm{~h}$ at $140^{\circ} \mathrm{C}$, using CHNS reactor

\begin{tabular}{lllllll}
\hline Foodstuff & \multicolumn{3}{l}{ Elemental composition $(\%){ }^{*}$ dab } & \multicolumn{3}{c}{ Reference } \\
\cline { 2 - 6 } & Carbon & Hydrogen & Nitrogen & Oxygen & Sulfur \\
\hline Carrots & 41.50 & 5.43 & 1.41 & 51.66 & - & This study \\
& 40.30 & 5.60 & 1.30 & 52.80 & 0.31 & {$[46]$} \\
& 42.82 & 5.14 & 1.50 & 50.23 & - & {$[47]$} \\
Cucumbers & 56.73 & 6.48 & 3.94 & 32.85 & - & This study \\
& 57.36 & 6.82 & 3.63 & 32.06 & 0.13 & {$[47]$} \\
Tomatoes & 49.72 & 7.38 & 3.74 & 39.16 & - & This study \\
& 49.69 & 7.43 & 3.78 & 39.10 & - & {$[48]$} \\
Carrots and cucumbers & 49.31 & 5.99 & 2.50 & 42.20 & - & This study \\
Carrots, cucumbers, and tomatoes & 49.28 & 6.38 & 2.86 & 41.48 & - & This study \\
\hline
\end{tabular}

*dab, dry and ash-free basis; ${ }^{* *}$ determined by difference. 


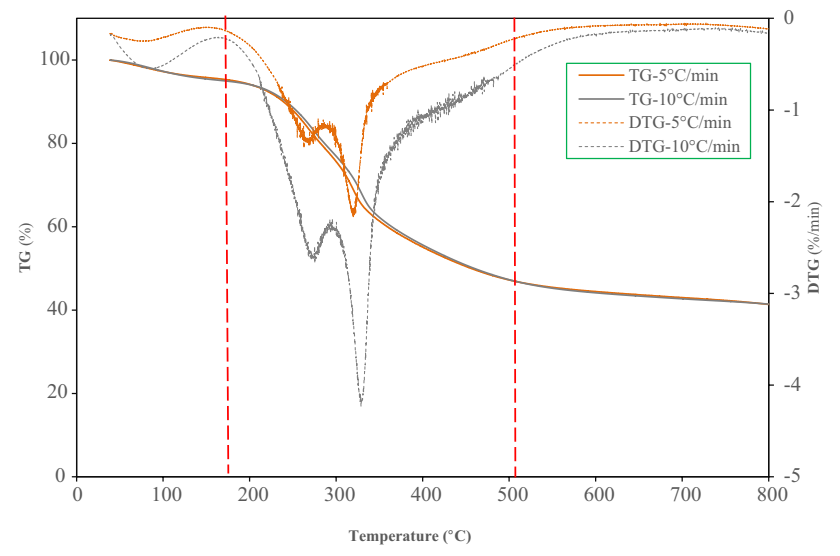

Fig. 2 TGA/DTGA profiles for the carrots single component at 5 and $10^{\circ} \mathrm{C} / \mathrm{min}$ heating rates

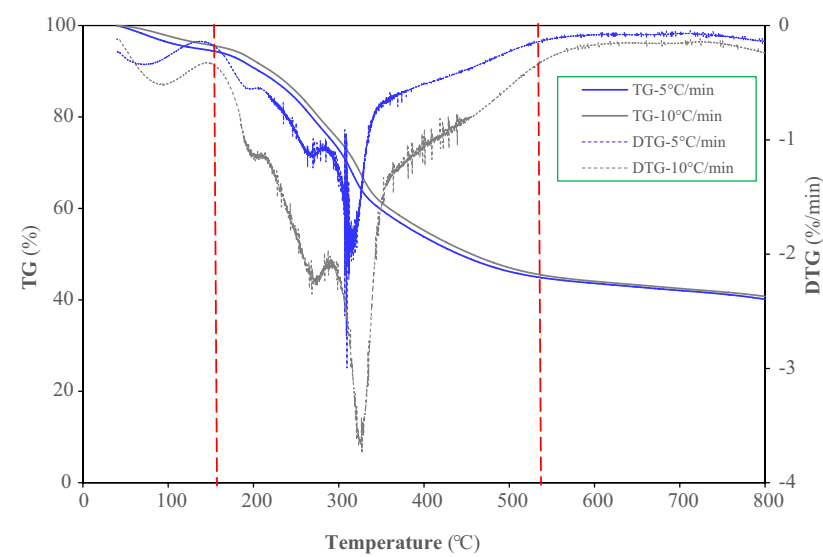

Fig. 3 TGA/DTGA profiles for the carrots and cucumbers blend at 5 and $10^{\circ} \mathrm{C} / \mathrm{min}$ heating rates

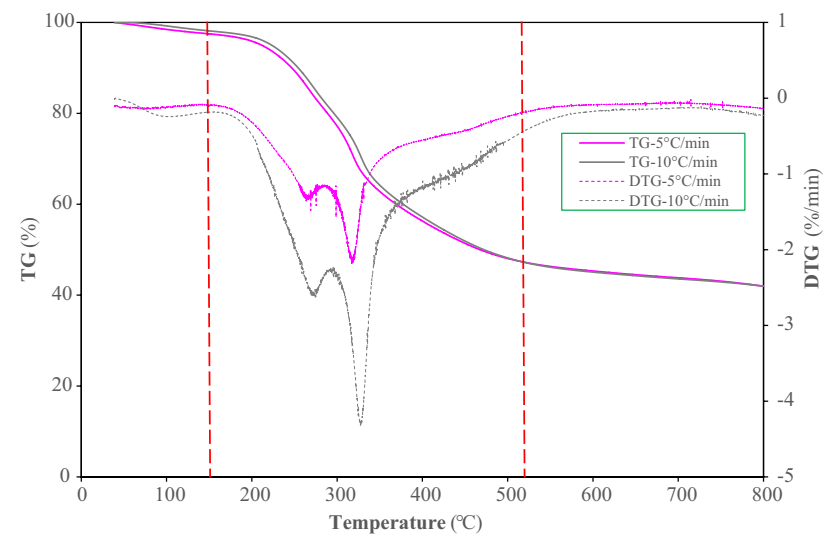

Fig. 4 TGA/DTGA profiles for the carrots, cucumbers, and tomatoes ternary blend at 5 and $10^{\circ} \mathrm{C} / \mathrm{min}$ heating rates
Table 5 presents the mass yields at different temperatures on a dry mass basis by taking the moisture content into account and dividing by the dryness fraction for the mass values $5{ }^{\circ} \mathrm{C} / \mathrm{min}$. For a system at a fixed heating rate, the height of the first peak of the DTGA corresponds to moisture content (wt.\%), which is then converted to the solid dryness fraction (100-moisture content) and then used to divide the original mass yields to arrive at the corrected dry mass yields in Tables 5 and 6 . The intention of these tables is to see if blending vegetable food wastes made any difference to the biochar yields.

The data in Table 5 show a steady decreasing trend in the mass fraction biochar product yield with increasing temperature for all three systems studied. The mass fractions showed, when multiplied by 100 , represent the solid percentage yields. The single-component carrot has a higher yield at each temperature. This could be caused by the other two systems (binary and ternary) having moister and softer interiors associated with higher cellulose contents than carrots.

In Table 6, for the single component, the char yield at $800{ }^{\circ} \mathrm{C}$ is 0.457 , the char yield for the binary is 0.415 , and for the ternary component, the yield is 0.383 . At $700{ }^{\circ} \mathrm{C}$, the yields are $0.468,0.436$, and 0.406 for single, binary, and ternary systems, respectively. There is a slight trend showing a decrease in the mass yield with blending at both 700 and $800{ }^{\circ} \mathrm{C}$, but at the heating rate of $5^{\circ} \mathrm{C} / \mathrm{min}$, the differences in the yields are quite small. Considering the data at the higher heating rate of $10^{\circ} \mathrm{C} / \mathrm{min}$ and $800{ }^{\circ} \mathrm{C}$, the single component carrot has the highest yield while the ternary component has the lowest yield.

As in the case of the lower heating rate, there is a slight trend in decreasing biochar formation with an increasing number of blended materials. In addition, the biochar yield is lower at the more rapid heating rate, which is well established in pyrolysis studies, so concluding there is more syngas and bio-oil produced with increased heating rate.

Figures 5 and 6 present the percentage char yields at different temperatures based on dry solids content at 5 and $10{ }^{\circ} \mathrm{C} / \mathrm{min}$, respectively.

Figures 5 and 6 demonstrate a slight difference in biochar yields at 600,700 , and $800^{\circ} \mathrm{C}$. The char yield for the single component is minimal at both heating rates, whereas it is high for the ternary system, as seen in the figures. The char yield of the binary component lies between the char yield of single and ternary components. In the case of $5^{\circ} \mathrm{C} / \mathrm{min}$, the biochar yield of the single, binary, and ternary component was observed to be $44.2 \%, 43.0 \%$, and $42.2 \%$ respectively, whereas, in the case of $10{ }^{\circ} \mathrm{C} / \mathrm{min}$, the biochar yield of the single, binary, and ternary component was observed to be $45.7 \%, 41.5 \%$, and $38.3 \%$, respectively. The biochar yields of 
Table 5 Dry mass yields, as mass fractions, while taking the moisture content into account and dividing by the dryness fraction for $5^{\circ} \mathrm{C} / \mathrm{min}$

\begin{tabular}{lllllllll}
\hline System & Dryness fraction & \multicolumn{2}{l}{ Temperature } \\
\cline { 3 - 8 } & & $300^{\circ} \mathrm{C}$ & $400{ }^{\circ} \mathrm{C}$ & $500{ }^{\circ} \mathrm{C}$ & $600{ }^{\circ} \mathrm{C}$ & $700^{\circ} \mathrm{C}$ & $800{ }^{\circ} \mathrm{C}$ \\
\hline Carrots & 0.95 & 0.827 & 0.600 & 0.505 & 0.463 & 0.453 & 0.442 \\
Carrots and cucumbers & 0.94 & 0.787 & 0.585 & 0.500 & 0.479 & 0.450 & 0.425 \\
Carrots, cucumbers, and tomato & 0.93 & 0.785 & 0.570 & 0.484 & 0.450 & 0.424 & 0.408 \\
\hline
\end{tabular}

Table 6 Dry mass yields, as mass fractions, while taking the moisture content into account and dividing by the dryness fraction for $10^{\circ} \mathrm{C} / \mathrm{min}$

\begin{tabular}{lllllllll}
\hline System & Dryness fraction & \multicolumn{2}{l}{ Temperature } \\
\cline { 3 - 8 } & & $300^{\circ} \mathrm{C}$ & $400{ }^{\circ} \mathrm{C}$ & $500^{\circ} \mathrm{C}$ & $600{ }^{\circ} \mathrm{C}$ & $700{ }^{\circ} \mathrm{C}$ & $800^{\circ} \mathrm{C}$ \\
\hline Carrots & 0.94 & 0.826 & 0.596 & 0.500 & 0.479 & 0.468 & 0.457 \\
Carrots and cucumbers & 0.94 & 0.819 & 0.585 & 0.489 & 0.468 & 0.436 & 0.415 \\
Carrots, cucumbers, and tomato & 0.94 & 0.812 & 0.556 & 0.476 & 0.429 & 0.406 & 0.383 \\
\hline
\end{tabular}

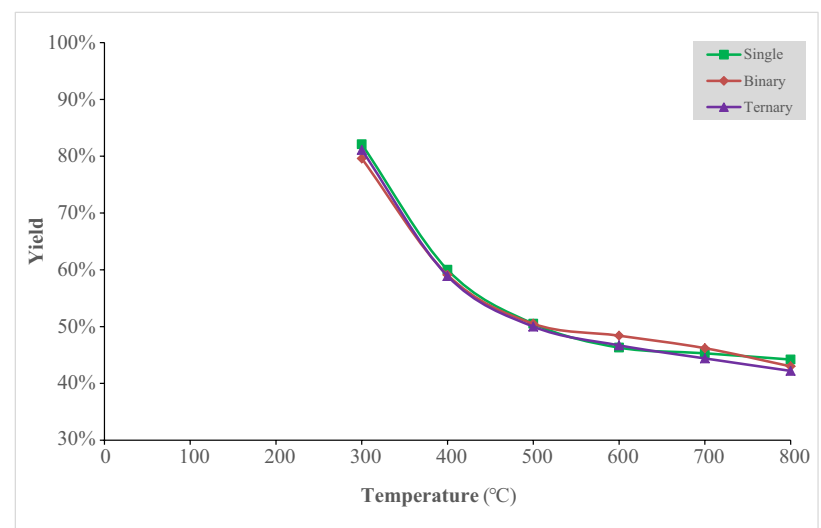

Fig. 5 Percentage char yields at different temperatures based on dry solids content at $5^{\circ} \mathrm{C} / \mathrm{min}$ heating rate

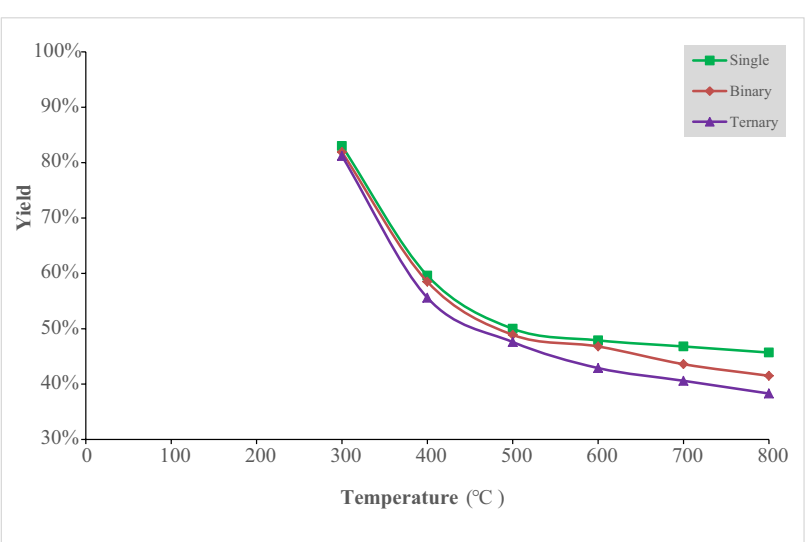

Fig. 6 Percentage char yields at different temperatures based on dry solids content at $10^{\circ} \mathrm{C} / \mathrm{min}$ heating rate

the current work are compared with biochar yields of other similar works in Table 7.
Table 7 Literature values for biochar yield at high temperatures

\begin{tabular}{lllll}
\hline Biomass type & $\begin{array}{l}\text { Heating } \\
\text { rate }\left({ }^{\circ} \mathrm{C} /\right. \\
\text { min) }\end{array}$ & $\begin{array}{l}\text { Biochar } \\
\text { yield } \\
(\%)\end{array}$ & $\begin{array}{l}\text { Tem- } \\
\text { perature } \\
\left({ }^{\circ} \mathrm{C}\right)\end{array}$ & References \\
\hline Cereal & 5 & $\sim 20$ & 700 & {$[13]$} \\
Meat & 5 & $\sim 18$ & 700 & \\
Vegetable & 5 & $\sim 38$ & 700 & \\
Mixed food & 5 & $\sim 28$ & 700 & \\
$\begin{array}{l}\text { Lignin-plastic mixture } \\
\text { Lignin-bone mixture }\end{array}$ & 10 & $\sim 30$ & 900 & {$[50]$} \\
$\begin{array}{l}\text { Bone-plastic mixture } \\
\text { Lignin-bone-plastic }\end{array}$ & 10 & $\sim 34$ & 900 & \\
mixture & 10 & $\sim 38$ & 900 & \\
\hline
\end{tabular}

\subsection{Food waste decomposition mechanism}

Inspection of Figs. 2, 3, and 4 at both heating rates, the total mass losses at $800{ }^{\circ} \mathrm{C}$ temperature is approximately $58-64 \%$; however, the main volatilization fraction of the food waste biomasses is taking place between 180 and $510{ }^{\circ} \mathrm{C}$. This significant volatile release may be assigned to the thermal decomposition of the three major food biomass constituents, namely: lignin, cellulose, and hemicellulose. These three constituent compounds have been well established as being responsible for this major mass loss during the pyrolysis process [51].

Furthermore, the presence of specific peaks can be observed in the DTGA results curves, representing the maximum reaction rates at both the heating rates. The initial peak can be seen in the region of $100-120{ }^{\circ} \mathrm{C}$ and is attributed to the evaporation of the moisture, for the current samples (because of the drying pretreatment), the mass loss is low in the region of $3-7 \%$. The second DTGA peak can be observed in the region $250-270{ }^{\circ} \mathrm{C}$ for both heating rates 5 and $10{ }^{\circ} \mathrm{C} / \mathrm{min}$. This peak is principally attributed to the pyrolytic decomposition of hemicellulose. Several 
other studies have reported in the scientific literature that hemicelluloses decompose in the $150-300{ }^{\circ} \mathrm{C}$ temperature range [52-55]. The third and final main peak is observed at $300-320{ }^{\circ} \mathrm{C}$ for both the heating rates. This peak is mainly attributed to cellulose itself, which generally undergoes degradation at quite high temperatures i.e. $300-400{ }^{\circ} \mathrm{C}[31,52$, 54]. In addition, the first biomass constituent to undergo decomposition at small temperatures is lignin itself, and its degradation occurs slowly at a very low reaction rate and proceeds right through the pyrolysis period until $800{ }^{\circ} \mathrm{C}$ with some peaking around $500{ }^{\circ} \mathrm{C}$. Consequently, this implies that small sections of the second and third peaks on the DTGA curves are associated with the decomposition of lignin [56]. Nevertheless, there is quite a degree of similarity between curves generated at the two different heating rates applied in this study. The peaks themselves represent the same structure and composition, and the mass loss trends follow the same direction, particularly at the higher temperatures, but the quantitative amounts, although the differences are quite small, do represent a significant change in the relative quantities of product formation. This trend in product distribution change due to variations in the heating rate has also been reported in the literature $[53,57]$. In the present study, it should be noted that the low heating rates were selected to investigate the slow pyrolysis, which has been shown to produce higher yields of product biochar.

\subsection{Kinetic analysis}

\subsubsection{Arrhenius model}

The TGA data are used to define Eq. (4), and the triplet kinetic parameters-pre-exponential factor, activation energy, and order of reaction were determined using a multiple linear regression equation in Microsoft excel. Only the kinetic parameters for the active pyrolysis zone $\left(140-620^{\circ} \mathrm{C}\right)$ were determined. The determined kinetic parameters for the food wastes at two different heating rates are presented in Table 8 . The obtained $\mathrm{R}^{2}$ values lie between 0.80 and 0.98 , indicating the good fitness of the model. The $R^{2}$ values for all the runs were in the range of 0.80 and 0.98 .
As can be seen from the table that the pre-exponential factor values for all the runs are in the range of $7.54 \times 10^{4}-8.62 \times 10^{6}\left(\mathrm{~s}^{-1}\right)$. This low range of $\left(<10^{9} \mathrm{~s}^{-1}\right)$ pre-exponential factor values indicates that the pyrolysis of the food wastes could be a surface reaction or closed complex reaction [58]. The activation energy values for the samples were between 15 and $26 \mathrm{~kJ} / \mathrm{mol}$. This low range of activation energy values signifies that the pyrolysis of the wastes would be simple and smooth. The reason for these low activation energy values could be due to their high cellulose and hemicellulose content and low lignin content. In general, the pyrolysis of cellulose and hemicellulose is simple and hence requires low activation energies while the pyrolysis of lignin is intricate, hence it needs high activation energies [40]. The order of reaction for all the wastes was between 0.75 and 0.89 .

The obtained values of the kinetic parameters are compared with the kinetic values of other works. Mansaray and Ghaly [59] were one of the pioneers to employ the Arrhenius model for determining the pyrolytic kinetics of plant biomass wastes. The researchers used the model to determine pyrolysis kinetics of different varieties of rice husk. The estimated pre-exponential factor values were in the range of $1.97 \times 10^{12}-2.03 \times 10^{15}\left(\mathrm{~s}^{-1}\right)$, while the activation energy values were between 142 and $189(\mathrm{~kJ}$ $\mathrm{mol}^{-1}$ ), and the orders of the reaction were between 0.70 and 0.83. Kumar et al. [60] employed the model to determine the kinetic parameters of corn stover pyrolysis. The triplet kinetic parameters for the active zone were in the range of $1.35 \times 10^{4}-7.33 \times 10^{4}\left(\mathrm{~s}^{-1}\right), 57-63\left(\mathrm{~kJ} \mathrm{~mol}^{-1}\right)$, and 0.74-0.73, respectively. Wu et al. [61] used the model to estimate the kinetic parameters of dairy manure pyrolysis. The pre-exponential factor, activation energy, and order of reaction for the active pyrolysis region were estimated to be $7.03 \times 10^{6}\left(\mathrm{~min}^{-1}\right), 93.63\left(\mathrm{~kJ} \mathrm{~mol}^{-1}\right)$, and 6.37 , respectively.

The kinetic parameters are primarily influenced by the nature of feedstocks, the composition of components present in the feedstocks, temperature range, and heating rate. Hence, a difference in the values of kinetic parameters is observed in all the studies.
Table 8 Kinetic parameters determined using Arrhenius model

\begin{tabular}{lllll}
\hline Foodstuff & $\begin{array}{l}\text { Heating rate } \\
\left({ }^{\circ} \mathrm{C} / \mathrm{min}\right)\end{array}$ & $\begin{array}{l}\text { Pre-exponential } \\
\text { factor }\left(\mathrm{s}^{-1}\right)\end{array}$ & $\begin{array}{l}\text { Activation energy } \\
\left(\mathrm{kJ} \mathrm{mol}^{-1}\right)\end{array}$ & $\begin{array}{l}\text { Order of } \\
\text { reaction } \\
(-)\end{array}$ \\
\hline Carrots & 5 & $5.44 \times 10^{5}$ & 25.88 & 0.88 \\
& 10 & $8.62 \times 10^{5}$ & 25.57 & 0.87 \\
Carrots and cucumbers & 5 & $7.54 \times 10^{4}$ & 17.25 & 0.75 \\
Carrots, cucumbers, and tomato & 5 & $1.68 \times 10^{5}$ & 16.62 & 0.76 \\
& 10 & $4.29 \times 10^{5}$ & 21.22 & 0.89 \\
& 10 & $2.89 \times 10^{5}$ & 15.81 & 0.80 \\
\hline
\end{tabular}




\subsubsection{CR model}

In this model, plotting $\ln \left[\frac{g(\alpha)}{T^{2}}\right]$ vs $\frac{1}{T}$ gives a slope from which activation energy $(E)$ is calculated. Among the reaction models, only the models that are good fitting with the experimental values are considered, and the kinetic parameters obtained from them are provided in Table 9.

As can be seen that first-order reaction (F1) is the bestfitting model. This indicates that first-order reaction is dominant in the active pyrolysis zones of all chosen vegetable food wastes. The pre-exponential factor values for all the wastes were below $10^{2}\left(\mathrm{~s}^{-1}\right)$, indicating that the pyrolysis of these wastes would undergo degradation smoothly without any complication. The obtained activation energy values ranged between 28 and $77 \mathrm{~kJ} \mathrm{~mol}^{-1}$. The $\mathrm{F} 1$ mechanism exhibited the lowest $E$-value, while the D3 model demonstrated the highest $E$-value.

\subsection{Thermodynamic properties}

The kinetic parameters of the good fitting models were used to determine the thermodynamic properties such as enthalpy
$(\Delta H)$, Gibbs free energy $(\Delta G)$, and entropy $(\Delta S)$. The thermodynamic properties values were calculated using the following equations:

$\Delta H=E-R T_{p}$

$\Delta G=E+R T_{p} \ln \left(\frac{k_{b} T_{p}}{h A}\right)$

$\Delta S=\frac{\Delta H-\Delta G}{T_{p}}$

where $R$ represents the gas constant having the value $8.314 \mathrm{~J} \mathrm{~mol}^{-1} \mathrm{~K}^{-1}, T_{p}$ corresponds to the peak decomposition temperature $(\mathrm{K}), k_{b}$ denotes the Boltzmann constant $\left(1.38 \times 10^{-23} \mathrm{~J} \mathrm{~K}^{-1}\right)$, and $h$ stands for Planck constant $\left(6.63 \times 10^{-34} \mathrm{Js}\right)$. The thermodynamic properties of the vegetable food wastes determined using different reaction mechanisms of the CR model are listed in Table 10.

$\Delta H$ is a state function of thermodynamic phenomena which indicates whether a system takes or emits heat. As can be noted from the table that $\Delta H$ values are between 26 and $72 \mathrm{~kJ} \mathrm{~mol}^{-1}$. The positive values of $\Delta H$ for all the models

Table 9 Kinetic parameters of vegetable food waste samples determined using different reaction models

\begin{tabular}{|c|c|c|c|c|c|}
\hline Vegetable food wastes & $\begin{array}{l}\text { Heating rate }\left({ }^{\circ} \mathrm{C} /\right. \\
\text { min) }\end{array}$ & Reaction order-based models & $A\left(\mathrm{~s}^{-1}\right)$ & $E\left(\mathrm{~kJ} \mathrm{~mol}^{-1}\right)$ & $R^{2}$ \\
\hline \multirow[t]{8}{*}{ Carrots } & \multirow[t]{4}{*}{5} & First-order $\left(\mathrm{F}_{1}\right)$ & $9.41 \times 10^{-1}$ & 37.85 & 0.90 \\
\hline & & Two-way transport $\left(\mathrm{D}_{2}\right)$ & $6.05 \times 10^{1}$ & 67.18 & 0.83 \\
\hline & & Three-way transport $\left(\mathrm{D}_{3}\right)$ & $1.21 \times 10^{2}$ & 75.56 & 0.88 \\
\hline & & Ginstling-Brounshtein $\left(\mathrm{D}_{4}\right)$ & $2.70 \times 10^{1}$ & 69.84 & 0.84 \\
\hline & \multirow[t]{4}{*}{10} & First-order $\left(\mathrm{F}_{1}\right)$ & 1.92 & 38.57 & 0.90 \\
\hline & & Two-way transport $\left(\mathrm{D}_{2}\right)$ & $1.18 \times 10^{2}$ & 68.11 & 0.81 \\
\hline & & Three-way transport $\left(\mathrm{D}_{3}\right)$ & $2.44 \times 10^{2}$ & 76.80 & 0.87 \\
\hline & & Ginstling-Brounshtein $\left(\mathrm{D}_{4}\right)$ & $5.34 \times 10^{1}$ & 70.86 & 0.83 \\
\hline \multirow[t]{8}{*}{ Carrots and cucumbers } & \multirow[t]{4}{*}{5} & First-order $\left(\mathrm{F}_{1}\right)$ & $3.42 \times 10^{-1}$ & 32.40 & 0.89 \\
\hline & & Two-way transport $\left(\mathrm{D}_{2}\right)$ & 9.34 & 56.58 & 0.80 \\
\hline & & Three-way transport $\left(\mathrm{D}_{3}\right)$ & $1.86 \times 10^{1}$ & 64.78 & 0.87 \\
\hline & & Ginstling-Brounshtein $\left(D_{4}\right)$ & 4.18 & 59.17 & 0.82 \\
\hline & \multirow[t]{4}{*}{10} & First-order $\left(\mathrm{F}_{1}\right)$ & $4.98 \times 10^{-1}$ & 31.55 & 0.89 \\
\hline & & Two-way transport $\left(\mathrm{D}_{2}\right)$ & $1.07 \times 10^{1}$ & 54.88 & 0.80 \\
\hline & & Three-way transport $\left(\mathrm{D}_{3}\right)$ & $2.12 \times 10^{1}$ & 63.15 & 0.86 \\
\hline & & Ginstling-Brounshtein $\left(\mathrm{D}_{4}\right)$ & 4.76 & 57.49 & 0.82 \\
\hline \multirow[t]{8}{*}{ Carrots, cucumbers, and tomatoes } & \multirow[t]{4}{*}{5} & First-order $\left(\mathrm{F}_{1}\right)$ & $3.09 \times 10^{-1}$ & 32.49 & 0.90 \\
\hline & & Two-way transport $\left(\mathrm{D}_{2}\right)$ & 7.38 & 56.59 & 0.81 \\
\hline & & Three-way transport $\left(\mathrm{D}_{3}\right)$ & $1.50 \times 10^{1}$ & 64.90 & 0.87 \\
\hline & & Ginstling-Brounshtein $\left(\mathrm{D}_{4}\right)$ & 3.31 & 59.21 & 0.83 \\
\hline & \multirow[t]{4}{*}{10} & First-order $\left(\mathrm{F}_{1}\right)$ & $3.03 \times 10^{-1}$ & 28.97 & 0.90 \\
\hline & & Two-way transport $\left(\mathrm{D}_{2}\right)$ & 3.79 & 49.43 & 0.80 \\
\hline & & Three-way transport $\left(\mathrm{D}_{3}\right)$ & 7.95 & 57.78 & 0.87 \\
\hline & & Ginstling-Brounshtein $\left(\mathrm{D}_{4}\right)$ & 1.71 & 52.05 & 0.83 \\
\hline
\end{tabular}


Table 10 Thermodynamic parameters of the vegetable food waste samples calculated using the CR model

\begin{tabular}{|c|c|c|c|c|c|}
\hline Vegetable food waste & $\begin{array}{l}\text { Heating rate } \\
\left({ }^{\circ} \mathrm{C} / \mathrm{min}\right)\end{array}$ & Reaction order-based models & $\Delta H\left(\mathrm{~kJ} \mathrm{~mol}^{-1}\right)$ & $\Delta G\left(\mathrm{~kJ} \mathrm{~mol}^{-1}\right)$ & $\Delta S\left(\mathrm{~kJ} \mathrm{~mol}^{-1} \mathrm{~K}^{-1}\right)$ \\
\hline \multirow[t]{8}{*}{ Carrots } & \multirow[t]{4}{*}{5} & First order $(\mathrm{F} 1)$ & 32.92 & 186.76 & -0.2594 \\
\hline & & Two-way transport (D2) & 62.25 & 195.57 & -0.2248 \\
\hline & & Three-way transport (D3) & 70.63 & 200.55 & -0.2191 \\
\hline & & Ginstling-Brounshtein (D4) & 64.90 & 202.20 & -0.2315 \\
\hline & \multirow[t]{4}{*}{10} & First order $(\mathrm{F} 1)$ & 33.57 & 186.22 & -0.2536 \\
\hline & & Two-way transport (D2) & 63.11 & 195.16 & -0.2194 \\
\hline & & Three-way transport (D3) & 71.80 & 200.21 & -0.2133 \\
\hline & & Ginstling-Brounshtein (D4) & 65.85 & 201.88 & -0.2260 \\
\hline \multirow[t]{8}{*}{ Carrots and cucumbers } & \multirow[t]{4}{*}{5} & First order $(\mathrm{F} 1)$ & 27.55 & 183.57 & -0.2677 \\
\hline & & Two-way transport (D2) & 51.73 & 191.73 & -0.2402 \\
\hline & & Three-way transport (D3) & 59.93 & 196.58 & -0.2345 \\
\hline & & Ginstling-Brounshtein (D4) & 54.33 & 198.23 & -0.2469 \\
\hline & \multirow[t]{4}{*}{10} & First order $(\mathrm{F} 1)$ & 26.56 & 185.62 & -0.2648 \\
\hline & & Two-way transport (D2) & 49.89 & 193.64 & -0.2394 \\
\hline & & Three-way transport (D3) & 58.16 & 198.48 & -0.2336 \\
\hline & & Ginstling-Brounshtein (D4) & 52.50 & 200.29 & -0.2461 \\
\hline \multirow[t]{8}{*}{ Carrots, cucumber, and tomatoes } & \multirow[t]{4}{*}{5} & First order $(\mathrm{F} 1)$ & 27.60 & 185.70 & -0.2686 \\
\hline & & Two-way transport (D2) & 51.69 & 194.27 & -0.2423 \\
\hline & & Three-way transport (D3) & 60.01 & 199.10 & -0.2363 \\
\hline & & Ginstling-Brounshtein (D4) & 54.32 & 200.81 & -0.2489 \\
\hline & \multirow[t]{4}{*}{10} & First order $(\mathrm{F} 1)$ & 24.00 & 162.16 & -0.2310 \\
\hline & & Two-way transport (D2) & 44.45 & 192.73 & -0.2479 \\
\hline & & Three-way transport (D3) & 52.81 & 197.40 & -0.2418 \\
\hline & & Ginstling-Brounshtein (D4) & 47.08 & 199.30 & -0.2545 \\
\hline
\end{tabular}

signify that the energy is required from an external source to reach the transition state. This indicates that only small external energy is sufficient to pyrolyze these vegetables' food wastes. The $\Delta G$ values are positive and are consistent $\left(162-202 \mathrm{~kJ} \mathrm{~mol}^{-1}\right)$. The positive values signify that the degradation phenomenon is an endergonic reaction. Negative $\Delta S$ values are observed for all the samples signifying the creation of activated complexes while small $\Delta S$ values indicate the slow reactivity of the samples.

\subsection{Syngas analysis results}

\subsubsection{TGA-MS profiles}

The TGA-MS profiles of carrot, carrot-cucumber, and carrot-cucumber-tomato are presented in Fig. 7.

As can be seen from Fig. 7, the peak release of $\mathrm{H}_{2} \mathrm{O}$ and $\mathrm{CO}_{2}$ occurs relatively at the same time, while the peak release of $\mathrm{CH}_{4}$ takes place a little later, followed by the evolution of $\mathrm{H}_{2}$. The release order of gases took place in the following order $\mathrm{H}_{2} \mathrm{O}, \mathrm{CO}_{2}, \mathrm{CH}_{4}$, and $\mathrm{H}_{2}$, which is consistent with the observation of Ma et al. [62]. In general, the liberation of the above gases is a complicated phenomenon as some gases evolve due to thermal degradation of feedstocks, some gases are adsorbed ones while the rest are released owing to secondary reactions among the product gases [63, 64]. It is significant to note that the ion-current intensities of $\mathrm{H}_{2} \mathrm{O}$ and $\mathrm{CO}_{2}$ are strong, indicating a high presence of hydroxyl groups and oxygen atoms in the selected food waste samples.

\subsubsection{Pyrolysis stages}

In general, based on the decomposition trend of the samples, the TG-DTG curves are classified into four stages: zeroth stage $\left({ }^{<} 150{ }^{\circ} \mathrm{C}\right)$, the first stage $\left(150-250{ }^{\circ} \mathrm{C}\right)$, the second stage $\left(250-500{ }^{\circ} \mathrm{C}\right)$, and the third stage $\left(>500{ }^{\circ} \mathrm{C}\right.$ ). The zeroth stage corresponds only to the dehydration phase, wherein no gas products are evolved, and it can be assumed that no pyrolysis occurs in this stage. In the first stage, gases such as $\mathrm{CH}_{4}, \mathrm{C}_{2} \mathrm{H}_{4}, \mathrm{C}_{2} \mathrm{H}_{6}$, and $\mathrm{H}_{2} \mathrm{O}$ are liberated. No permanent gases such as $\mathrm{H}_{2}$, $\mathrm{CO}, \mathrm{CO}_{2}$, and $\mathrm{O}_{2}$ are produced in this stage. In the second stage, most gas products except $\mathrm{H}_{2}$ are generated. The pyrolysis of biomass primarily occurs in this stage. In the third stage, biomass pyrolysis occurs with the production 
Fig. 7 TGA-MS profiles: a carrot at $5{ }^{\circ} \mathrm{C} / \mathrm{min}$, b carrot at $10^{\circ} \mathrm{C} / \mathrm{min}$, c carrot-cucumber at $5{ }^{\circ} \mathrm{C} / \mathrm{min}$, $\mathbf{d}$ carrot-cucumber at $10{ }^{\circ} \mathrm{C} / \mathrm{min}$, e carrot-cucumber-tomato at $5{ }^{\circ} \mathrm{C} / \mathrm{min}$, and f carrot-cucumber-tomato at $10{ }^{\circ} \mathrm{C} / \mathrm{min}$

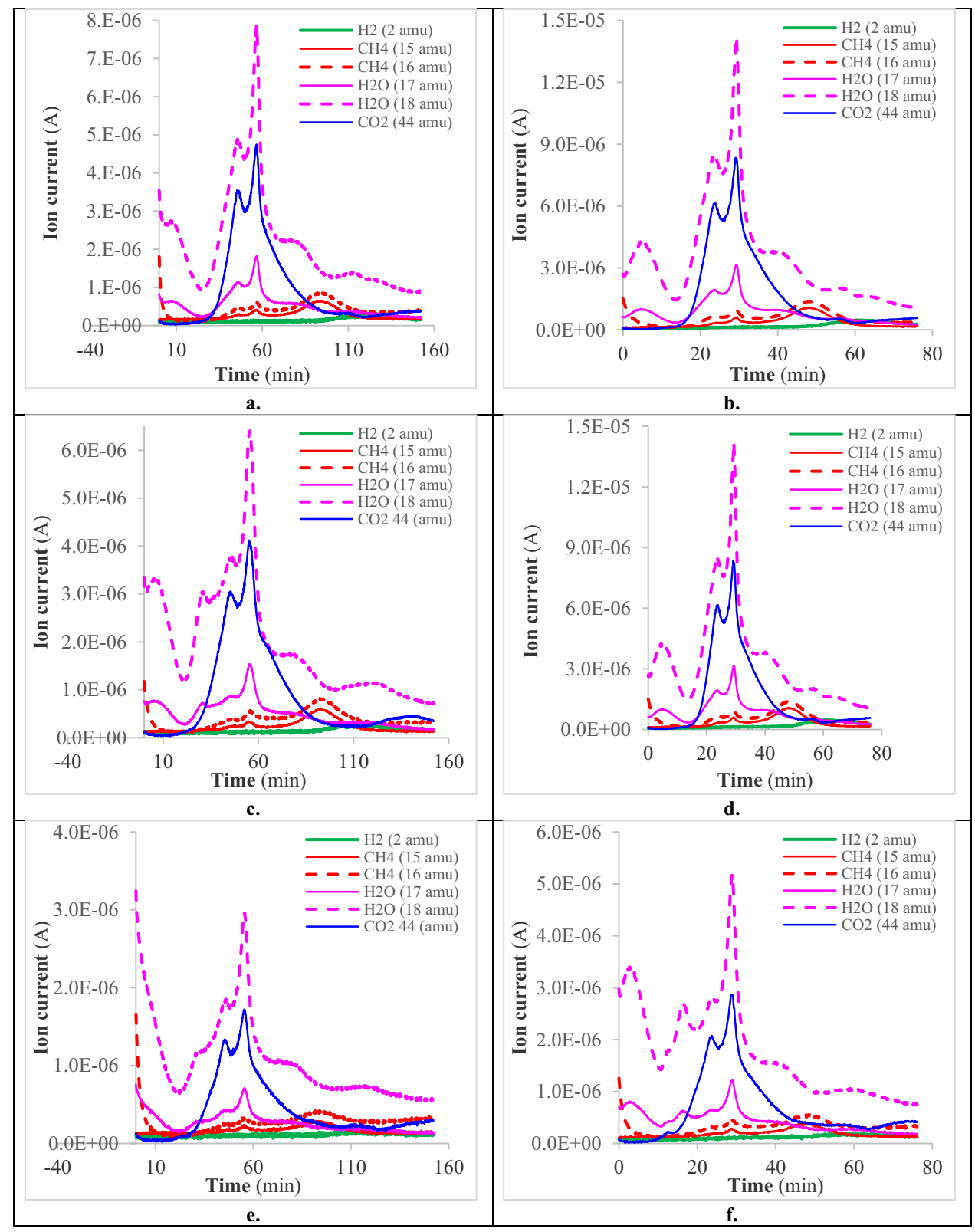

of $\mathrm{CO}_{2}$ and $\mathrm{H}_{2}$. The interaction between $\mathrm{CO}_{2}$ and $\mathrm{H}_{2}$ also takes place in this stage. Table 11 presents the detected gas components and their respective pyrolysis stages. The table also presents the details of peak ion current and peak temperature of the gas components, which are very vital for the quantification of the gas components.

From Table 11, it can be noted that the temperature of $\mathrm{H}_{2} \mathrm{O}$ peak lies between 202 and $332{ }^{\circ} \mathrm{C}$, the temperature of $\mathrm{CO}_{2}$ peak lies in the range $268-329^{\circ} \mathrm{C}$, the temperature of $\mathrm{CH}_{4}$ peak is ranges between 267 and $524{ }^{\circ} \mathrm{C}$, and the temperature of $\mathrm{H}_{2}$ peak falls in the $569-654{ }^{\circ} \mathrm{C}$ temperature range. The observed temperature ranges indicate that the release of $\mathrm{H}_{2} \mathrm{O}$ falls under the first and second stage of pyrolysis, the evolution of $\mathrm{CO}_{2}$ falling under the second stage of pyrolysis, the liberation of $\mathrm{CH}_{4}$ belongs to the second and third stage of pyrolysis, while the discharge of $\mathrm{H}_{2}$ belonging to the third stage of pyrolysis.

\subsubsection{Effect of heating rate on the syngas components yield}

Based on the equation, the volumetric compositions of $\mathrm{H}_{2}$, $\mathrm{CH}_{4}, \mathrm{H}_{2} \mathrm{O}$, and $\mathrm{CO}_{2}$ components were calculated, and the effect of heating rate on the syngas components yield is illustrated in Fig. 8.

It can be seen from the figure that increasing heating rate from 5 to $10{ }^{\circ} \mathrm{C} / \mathrm{min}$ produced an insignificant change in the $\mathrm{H}_{2}$ yield of all feedstock samples. 
Table 11 Evolved gas components and their respective pyrolysis stages

\begin{tabular}{|c|c|c|c|c|c|c|c|}
\hline Food waste & Heating rate & Gas component & $\mathrm{amu}$ & Stage & $\log 10$ & Peak ion current (A) & $\begin{array}{l}\text { Peak } \\
\text { temperature } \\
\left({ }^{\circ} \mathrm{C}\right)\end{array}$ \\
\hline \multirow[t]{13}{*}{ Carrot } & \multirow[t]{13}{*}{5} & $\mathrm{H}_{2}$ & 2 & Third & -6.55 & $2.80 \times 10^{-7}$ & 630.19 \\
\hline & & \multirow[t]{3}{*}{$\mathrm{CH}_{4}$} & \multirow[t]{3}{*}{15} & Second & -6.18 & $6.54 \times 10^{-7}$ & 495.84 \\
\hline & & & & Second & -6.38 & $4.16 \times 10^{-7}$ & 323.27 \\
\hline & & & & Second & -6.53 & $2.95 \times 10^{-7}$ & 271.00 \\
\hline & & \multirow[t]{3}{*}{$\mathrm{CH}_{4}$} & \multirow[t]{3}{*}{16} & Third & -6.07 & $8.51 \times 10^{-7}$ & 509.46 \\
\hline & & & & Second & -6.21 & $6.17 \times 10^{-7}$ & 322.19 \\
\hline & & & & Second & -6.34 & $4.52 \times 10^{-7}$ & 274.82 \\
\hline & & \multirow[t]{2}{*}{$\mathrm{H}_{2} \mathrm{O}$} & \multirow[t]{2}{*}{17} & Second & -5.74 & $1.82 \times 10^{-6}$ & 321.65 \\
\hline & & & & Second & -5.94 & $1.14 \times 10^{-6}$ & 268.25 \\
\hline & & \multirow[t]{2}{*}{$\mathrm{H}_{2} \mathrm{O}$} & \multirow[t]{2}{*}{18} & Second & -5.10 & $7.87 \times 10^{-6}$ & 321.11 \\
\hline & & & & Second & -5.31 & $4.85 \times 10^{-6}$ & 268.84 \\
\hline & & \multirow[t]{2}{*}{$\mathrm{CO}_{2}$} & \multirow[t]{2}{*}{44} & Second & -5.32 & $4.75 \times 10^{-6}$ & 322.73 \\
\hline & & & & Second & -5.45 & $3.56 \times 10^{-6}$ & 269.92 \\
\hline \multirow[t]{13}{*}{ Carrot } & \multirow[t]{13}{*}{10} & $\mathrm{H}_{2}$ & 2 & Third & -6.32 & $4.77 \times 10^{-7}$ & 654.23 \\
\hline & & \multirow[t]{3}{*}{$\mathrm{CH}_{4}$} & \multirow[t]{3}{*}{15} & Third & -5.97 & $1.07 \times 10^{-6}$ & 517.22 \\
\hline & & & & Second & -6.22 & $6.07 \times 10^{-7}$ & 329.77 \\
\hline & & & & Second & -6.46 & $3.50 \times 10^{-7}$ & 278.61 \\
\hline & & \multirow[t]{3}{*}{$\mathrm{CH}_{4}$} & \multirow[t]{3}{*}{16} & Third & -5.86 & $1.38 \times 10^{-6}$ & 520.62 \\
\hline & & & & Second & -6.03 & $9.40 \times 10^{-7}$ & 332.10 \\
\hline & & & & Second & -6.17 & $6.74 \times 10^{-7}$ & 279.69 \\
\hline & & \multirow[t]{2}{*}{$\mathrm{H}_{2} \mathrm{O}$} & \multirow[t]{2}{*}{17} & Second & -5.50 & $3.16 \times 10^{-6}$ & 332.02 \\
\hline & & & & Second & -5.71 & $1.94 \times 10^{-6}$ & 276.52 \\
\hline & & \multirow[t]{2}{*}{$\mathrm{H}_{2} \mathrm{O}$} & \multirow[t]{2}{*}{18} & Second & -4.85 & $1.42 \times 10^{-5}$ & 331.02 \\
\hline & & & & Second & -5.07 & $8.49 \times 10^{-6}$ & 275.34 \\
\hline & & \multirow[t]{2}{*}{$\mathrm{CO}_{2}$} & \multirow[t]{2}{*}{44} & Second & -5.08 & $8.34 \times 10^{-6}$ & 328.77 \\
\hline & & & & Second & -5.21 & $6.17 \times 10^{-6}$ & 274.26 \\
\hline \multirow[t]{13}{*}{ Carrot-cucumber } & 5 & $\mathrm{H}_{2}$ & 2 & Third & -6.61 & $2.45 \times 10^{-7}$ & 586.91 \\
\hline & & $\mathrm{CH}_{4}$ & 15 & Third & -6.23 & $5.95 \times 10^{-7}$ & 501.47 \\
\hline & & & & Second & -6.43 & $3.70 \times 10^{-7}$ & 314.16 \\
\hline & & & & Second & -6.59 & $2.56 \times 10^{-7}$ & 280.40 \\
\hline & & $\mathrm{CH}_{4}$ & 16 & Third & -6.08 & $8.25 \times 10^{-7}$ & 501.47 \\
\hline & & & & Second & -6.25 & $5.68 \times 10^{-7}$ & 318.49 \\
\hline & & & & Second & -6.40 & $3.98 \times 10^{-7}$ & 267.82 \\
\hline & & $\mathrm{H}_{2} \mathrm{O}$ & 17 & Second & -5.81 & $1.53 \times 10^{-6}$ & 318.49 \\
\hline & & & & Second & -6.05 & $8.83 \times 10^{-7}$ & 267.28 \\
\hline & & $\mathrm{H}_{2} \mathrm{O}$ & 18 & Second & -5.19 & $6.40 \times 10^{-6}$ & 318.49 \\
\hline & & & & Second & -5.42 & $3.76 \times 10^{-6}$ & 268.40 \\
\hline & & $\mathrm{CO}_{2}$ & 44 & Second & -5.76 & $1.72 \times 10^{-6}$ & 316.51 \\
\hline & & & & Second & -5.88 & $1.33 \times 10^{-6}$ & 268.62 \\
\hline
\end{tabular}

However, an elevation in heating rate brought about a decrease in the yields of $\mathrm{CH}_{4}$. An increase in heating rate produced a decrease in $\mathrm{H}_{2} \mathrm{O}$ yields of single and binary samples, while in the ternary sample an increase in $\mathrm{H}_{2} \mathrm{O}$ yield is noted. An elevation in heating rate also produced a mixed trend in the yield of $\mathrm{CO}_{2}$, i.e., a decrease in $\mathrm{CO}_{2}$ yield in the case of single and ternary samples and an increase in $\mathrm{CO}_{2}$ yield in the case of the binary sample.

\subsubsection{Effect of blending on the syngas component yield}

The effect of blending on the syngas components yield at heating rates 5 and $10^{\circ} \mathrm{C} / \mathrm{min}$ is presented in Fig. 9 . 
Table 11 (continued)

\begin{tabular}{|c|c|c|c|c|c|c|c|}
\hline Food waste & Heating rate & Gas component & $\mathrm{amu}$ & Stage & $\log 10$ & Peak ion current (A) & $\begin{array}{l}\text { Peak } \\
\text { temperature } \\
\left({ }^{\circ} \mathrm{C}\right)\end{array}$ \\
\hline \multirow[t]{13}{*}{ Carrot-cucumber } & \multirow[t]{13}{*}{10} & $\mathrm{H}_{2}$ & 2 & Third & -6.50 & $3.13 \times 10^{-7}$ & 569.45 \\
\hline & & \multirow[t]{3}{*}{$\mathrm{CH}_{4}$} & \multirow[t]{3}{*}{15} & Third & -6.10 & $8.03 \times 10^{-7}$ & 509.59 \\
\hline & & & & Second & -6.40 & $3.98 \times 10^{-7}$ & 325.37 \\
\hline & & & & Second & -6.56 & $2.75 \times 10^{-7}$ & 276.40 \\
\hline & & \multirow[t]{3}{*}{$\mathrm{CH}_{4}$} & \multirow[t]{3}{*}{16} & Third & -5.97 & $1.08 \times 10^{-6}$ & 520.43 \\
\hline & & & & Second & -6.17 & $6.81 \times 10^{-7}$ & 332.03 \\
\hline & & & & Second & -6.30 & $5.01 \times 10^{-7}$ & 270.90 \\
\hline & & \multirow[t]{2}{*}{$\mathrm{H}_{2} \mathrm{O}$} & \multirow[t]{2}{*}{17} & Second & -5.69 & $2.03 \times 10^{-6}$ & 330.87 \\
\hline & & & & Second & -5.92 & $1.21 \times 10^{-6}$ & 270.98 \\
\hline & & \multirow[t]{2}{*}{$\mathrm{H}_{2} \mathrm{O}$} & \multirow[t]{2}{*}{18} & Second & -5.06 & $8.64 \times 10^{-6}$ & 327.62 \\
\hline & & & & Second & -5.28 & $5.28 \times 10^{-6}$ & 270.90 \\
\hline & & \multirow[t]{2}{*}{$\mathrm{CO}_{2}$} & \multirow[t]{2}{*}{44} & Second & -5.26 & $5.50 \times 10^{-6}$ & 327.62 \\
\hline & & & & Second & -5.37 & $4.24 \times 10^{-6}$ & 273.15 \\
\hline \multirow[t]{12}{*}{ Carrot-cucumber-tomato } & \multirow[t]{12}{*}{5} & $\mathrm{H}_{2}$ & 2 & Third & -6.86 & $1.38 \times 10^{-7}$ & 615.00 \\
\hline & & \multirow[t]{3}{*}{$\mathrm{CH}_{4}$} & \multirow[t]{3}{*}{15} & Second & -6.56 & $2.73 \times 10^{-7}$ & 499.03 \\
\hline & & & & Second & -6.66 & $2.17 \times 10^{-7}$ & 319.23 \\
\hline & & & & Second & -6.77 & $1.71 \times 10^{-7}$ & 269.16 \\
\hline & & \multirow[t]{2}{*}{$\mathrm{CH}_{4}$} & \multirow[t]{2}{*}{16} & Third & -6.41 & $3.91 \times 10^{-7}$ & 503.90 \\
\hline & & & & Second & -6.51 & $3.11 \times 10^{-7}$ & 315.41 \\
\hline & & \multirow[t]{2}{*}{$\mathrm{H}_{2} \mathrm{O}$} & \multirow[t]{2}{*}{17} & Second & -6.15 & $7.10 \times 10^{-7}$ & 318.10 \\
\hline & & & & Second & -6.36 & $4.37 \times 10^{-7}$ & 269.16 \\
\hline & & \multirow[t]{2}{*}{$\mathrm{H}_{2} \mathrm{O}$} & \multirow[t]{2}{*}{18} & Second & -5.53 & $2.96 \times 10^{-6}$ & 318.10 \\
\hline & & & & Second & -5.73 & $1.86 \times 10^{-6}$ & 270.25 \\
\hline & & \multirow[t]{2}{*}{$\mathrm{CO}_{2}$} & \multirow[t]{2}{*}{44} & Second & -5.76 & $1.72 \times 10^{-6}$ & 316.47 \\
\hline & & & & Second & -5.88 & $1.32 \times 10^{-6}$ & 269.16 \\
\hline \multirow[t]{15}{*}{ Carrot-cucumber-tomato } & 10 & $\mathrm{H}_{2}$ & 2 & Third & -6.70 & $2.01 \times 10^{-7}$ & 654.74 \\
\hline & & $\mathrm{CH}_{4}$ & 15 & Third & -6.41 & $3.93 \times 10^{-7}$ & 505.80 \\
\hline & & & & Second & -6.55 & $2.79 \times 10^{-7}$ & 325.99 \\
\hline & & & & Second & -6.70 & $1.99 \times 10^{-7}$ & 281.28 \\
\hline & & $\mathrm{CH}_{4}$ & 16 & Third & -6.26 & $5.50 \times 10^{-7}$ & 523.26 \\
\hline & & & & Second & -6.34 & $4.62 \times 10^{-7}$ & 328.07 \\
\hline & & & & Second & -6.50 & $3.19 \times 10^{-7}$ & 274.76 \\
\hline & & $\mathrm{H}_{2} \mathrm{O}$ & 17 & Second & -5.91 & $1.22 \times 10^{-6}$ & 327.07 \\
\hline & & & & Second & -6.18 & $6.54 \times 10^{-7}$ & 273.68 \\
\hline & & & & First & -6.22 & $6.09 \times 10^{-7}$ & 202.83 \\
\hline & & $\mathrm{H}_{2} \mathrm{O}$ & 18 & Second & -5.28 & $5.19 \times 10^{-6}$ & 325.99 \\
\hline & & & & Second & -5.55 & $2.80 \times 10^{-6}$ & 273.68 \\
\hline & & & & First & -5.57 & $2.69 \times 10^{-6}$ & 202.83 \\
\hline & & $\mathrm{CO}_{2}$ & 44 & Second & -5.54 & $2.86 \times 10^{-6}$ & 323.74 \\
\hline & & & & Second & -5.68 & $2.07 \times 10^{-6}$ & 273.66 \\
\hline
\end{tabular}




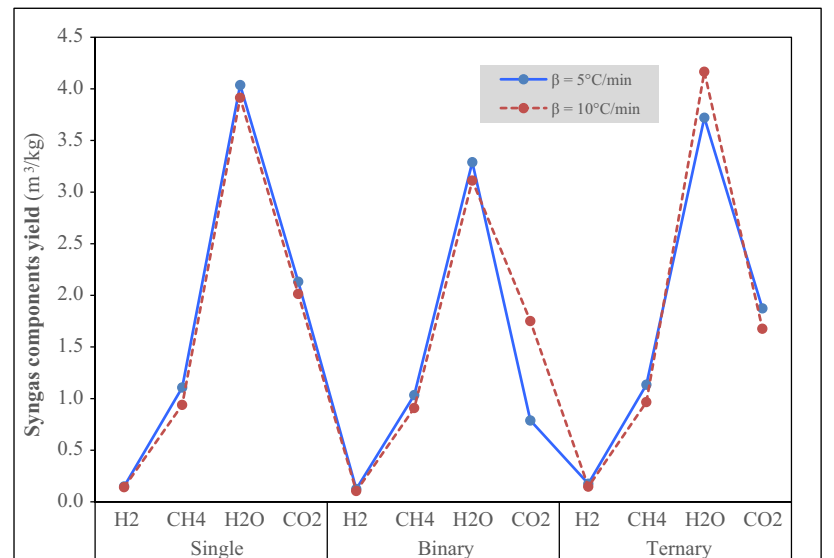

Fig. 8 Effect of heating rate on the syngas component yield

It is interesting to note that at both heating rates, the $\mathrm{H}_{2}$ yield is the highest for the ternary mixture followed by the single feedstock sample and then by the binary mixture. This indicates that the ternary mixture combination is encouraging the $\mathrm{H}_{2}$ yield. At heating rate of $5{ }^{\circ} \mathrm{C} / \mathrm{min}$, the $\mathrm{CH}_{4}, \mathrm{H}_{2} \mathrm{O}$, and $\mathrm{CO}_{2}$ yields of a single feedstock sample are more than the binary and ternary mixtures. At a heating rate of $10{ }^{\circ} \mathrm{C} /$ min as well, apart from the $\mathrm{H}_{2} \mathrm{O}$ yield, the yields of $\mathrm{CH}_{4}$ and $\mathrm{CO}_{2}$ are more than the binary and ternary mixtures. This indicates that the carrot favors more $\mathrm{CO}_{2}$ and $\mathrm{CH}_{4}$ production than cucumber and tomato upon pyrolysis. It is evident from the figure that the syngas yields of binary and ternary mixtures differ considerably and can be attributed to the differences in the cellulosic and hemicellulosic contents in the binary and ternary mixtures. Different syngas compositions in binary and ternary mixtures signify that the interaction between carrot-cucumber and carrot-cucumber-tomato is different. It also indicates the synergistic effect of feedstock samples.

\section{Conclusion}

The current work focuses on the understanding of the pyrolysis process and the generation of biochars from food waste. According to the TGA results, the endothermal peaks of hemicellulose, cellulose, and lignocellulose degradation took place at ranges close to those reported in the literature studies, namely, 220, 315, and $505{ }^{\circ} \mathrm{C}$, respectively. The biochar yields between 200 and $800{ }^{\circ} \mathrm{C}$ were in the range 82.7 to $40.8 w / w \%$ and 82.3 to $38.3 w / w \%$ at 5 and $10{ }^{\circ} \mathrm{C} / \mathrm{min}$, respectively. The biochar yields for the food waste blends were slightly lower than the yields for the individual food type. The gas analysis indicated that the ternary mixture produced the highest $\mathrm{H}_{2}$ yield, followed by the single feedstock sample and then by the binary mixture. Different syngas compositions in binary and ternary mixtures signify that the interaction between carrot-cucumber and carrot-cucumber-tomato is different. Further research should focus on the product distribution and yields from blends of food wastes but also on blends of food wastes with other types of waste to study these synergistic effects.
Fig. 9 Effect of blending on the syngas components yield at heating rates: a $5{ }^{\circ} \mathrm{C} / \mathrm{min} ; \mathbf{b} 10$ ${ }^{\circ} \mathrm{C} / \mathrm{min}$

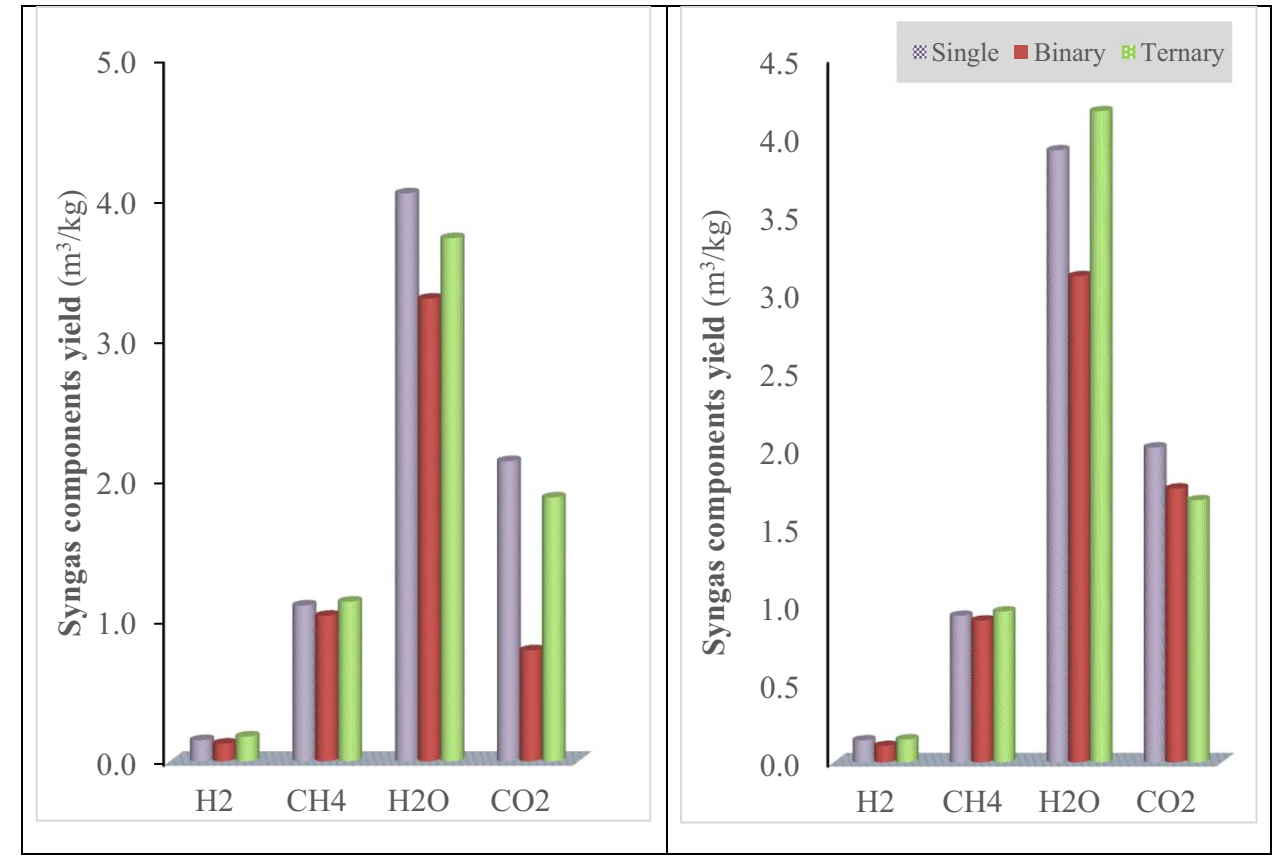


Supplementary Information The online version contains supplementary material available at https://doi.org/10.1007/s13399-022-02441-0.

Acknowledgements The authors would like to thank Hamad Bin Khalifa University (HBKU), under Qatar Foundation (QF), for supporting the research. The team also extends their gratitude to the QEERI core analytical laboratory facilities for the provision of their analytical support.

Author contribution Samar Elkhalifa: methodology, formal analysis, investigation, and writing-original draft preparation; Prakash Parthasarathy: investigation and writing-original draft preparation; Hamish Mackey: funding acquisition, resources, and project administration; Tareq Al-Ansari: funding acquisition, resources, and project administration; Omar Elhassan: formal analysis; Said Mansour: formal analysis; Gordon McKay: funding acquisition, project administration, resources, conceptualization, supervision, and reviewing and editing.

Funding Open Access funding provided by the Qatar National Library. The authors would like to thank the Qatar National Research Fund (QNRF) for the provision of an award under NPRP11S-0117-180328. Any opinions, findings, conclusions, or recommendations expressed in this material are those of the author(s) and do not necessarily reflect the views of QNRF.

Data availability The TGA and MS data file have been submitted as a separate file.

Code availability Not applicable.

\section{Declarations}

Conflict of interest The authors declare no competing interests.

Open Access This article is licensed under a Creative Commons Attribution 4.0 International License, which permits use, sharing, adaptation, distribution and reproduction in any medium or format, as long as you give appropriate credit to the original author(s) and the source, provide a link to the Creative Commons licence, and indicate if changes were made. The images or other third party material in this article are included in the article's Creative Commons licence, unless indicated otherwise in a credit line to the material. If material is not included in the article's Creative Commons licence and your intended use is not permitted by statutory regulation or exceeds the permitted use, you will need to obtain permission directly from the copyright holder. To view a copy of this licence, visit http://creativecommons.org/licenses/by/4.0/.

\section{References}

1. Parthasarathy P, Narayanan KS, Ceylan S, Pambudi NA (2017) Optimization of parameters for the generation of hydrogen in combined slow pyrolysis and steam gasification of biomass. Energy Fuels 31:13692-13704. https://doi.org/10.1021/acs.energyfuels. $7 b 02429$

2. Alherbawi M, Parthasarathy P, Al-Ansari T, Mackey H, McKay G (2021) Potential of drop-in biofuel production from camel manure by hydrothermal liquefaction and biocrude upgrading: a Qatar case study. Energy 232:121027. https://doi.org/10.1016/J. ENERGY.2021.121027

3. Al-Ansari T, AlNouss A, Al-Thani N, Parthasarathy P, ElKhalifa S, Mckay G, Alherbawi M (2020) Optimising multi biomass feedstock utilisation considering a multi technology approach. Comput Aided Chem Eng 48:1633-1638. https://doi.org/10.1016/ B978-0-12-823377-1.50273-1

4. Shahbaz M, Al-Ansari T, Inayat M, Sulaiman SA, Parthasarathy P, McKay G (2020) A critical review on the influence of process parameters in catalytic co-gasification: current performance and challenges for a future prospectus. Renew Sustain Energy Rev 134:110382

5. Shahbaz M, AlNouss A, Parthasarathy P, Abdelaal AH, Mackey H, McKay G, Al-Ansari T (2020) Investigation of biomass components on the slow pyrolysis products yield using Aspen Plus for techno-economic analysis. Biomass Convers Biorefin 10:1-13. https://doi.org/10.1007/S13399-020-01040-1/FIGURES/8

6. Elkhalifa S, Elhassan O, Parthasarathy P, Mackey H, Al-Ansari T, McKay G (2020) Thermogravimetric analysis of individual food waste items and their blends for biochar production

7. Pradhan S, Shahbaz M, Abdelaal A, Al-Ansari T, Mackey HR, McKay G (2020) Optimization of process and properties of biochar from cabbage waste by response surface methodology. Biomass Convers Biorefinery 2020:1-13. https://doi.org/10.1007/ S13399-020-01101-5

8. Aamer M, Shaaban M, Hassan MU, Guoqin H, Ying L, Hai Ying T, Rasul F, Qiaoying M, Zhuanling L, Rasheed A, Peng Z (2020) Biochar mitigates the $\mathrm{N} 2 \mathrm{O}$ emissions from acidic soil by increasing the nosZ and nirK gene abundance and soil $\mathrm{pH}$. J Environ Manage 255:109891. https://doi.org/10.1016/J.JENVMAN.2019. 109891

9. Khorram M, Lin D, Zhang Q, Zheng Y, Fang H, Yu Y (2017) Effects of aging process on adsorption-desorption and bioavailability of fomesafen in an agricultural soil amended with rice hull biochar. J Environ Sci 56:180-191. https://doi.org/10.1016/J.JES. 2016.09.012

10. Mia S, Uddin M, Kader M, Ahsan A, Mannan M, Hossain M, Solaiman Z (2018) Pyrolysis and co-composting of municipal organic waste in Bangladesh: a quantitative estimate of recyclable nutrients, greenhouse gas emissions, and economic benefits. Waste Manag 75:503-513. https://doi.org/10.1016/J.WASMAN. 2018.01.038

11. Jian J, Lu Z, Yao S, Li Y, Liu Z, Lang B, Chen Z (2019) Effects of thermal conditions on char yield and char reactivity of woody biomass in stepwise pyrolysis. J Anal Appl Pyrolysis 138:211-217. https://doi.org/10.1016/J.JAAP.2018.12.026

12. FAO (2021) Fruit and vegetables-your dietary essentials. The International Year of Fruits and Vegetables. https://doi.org/10. 4060/cb2395en

13. Jo JH, Kim SS, Shim JW, Lee YE, Yoo YS (2017) Pyrolysis characteristics and kinetics of food wastes. Energies 10:191. https:// doi.org/10.3390/en10081191

14. Nocera F, Gagliano A, Patania F, Bruno M, Scirè S (2016) Slow pyrolysis kinetics of apricots stones by thermogravimetric analysis. IREC 2016-7th International Renewable Energy Congress. Institute of Electrical and Electronics Engineers Inc, Hammamet

15. Li S, Chen G (2018) Thermogravimetric, thermochemical, and infrared spectral characterization of feedstocks and biochar derived at different pyrolysis temperatures. Waste Manag 78:198207. https://doi.org/10.1016/J.WASMAN.2018.05.048

16. Parthasarathy P, Mackey HR, Mariyam S, Zuhara S, Al-Ansari T, McKay G (2021) Char products from bamboo waste pyrolysis and acid activation. Front Mater 29:482. https://doi.org/10.3389/ FMATS.2020.624791

17. Parthasarathy P, Al-Ansari T, Mackey HM, McKay G (2021) Effect of heating rate on the pyrolysis of camel manure. Biomass Convers Biorefinery 2021:1-13. https://doi.org/10.1007/ S13399-021-01531-9

18. Naqvi SR, Tariq R, Shahbaz M, Naqvi M, Aslam M, Khan Z, Mackey H, Mckay G, Al-Ansari T (2021) Recent developments 
on sewage sludge pyrolysis and its kinetics: resources recovery, thermogravimetric platforms, and innovative prospects. Comput Chem Eng 150:107325. https://doi.org/10.1016/J.COMPC HEMENG.2021.107325

19. AlNouss A, Parthasarathy P, Mackey HR, Al-Ansari T, McKay G (2021) Pyrolysis study of different fruit wastes using an Aspen plus model. Front Sustain Food Syst 5:604001. https://doi.org/10. 3389/fsufs.2021.604001

20. Elkhalifa S, Al-Ansari T, Mackey HR, McKay G (2019) Food waste to biochars through pyrolysis: a review. Resour Conserv Recycl 144:310-320

21. Elkhalifa S, AlNouss A, Al-Ansari T, Mackey HR, Parthasarathy P, Mckay G (2019) Simulation of food waste pyrolysis for the production of biochar: a Qatar case study. Comput Aided Chem Eng 46:901-906

22. Liang S, Han Y, Wei L, Mcdonald AG (2015) Production and characterization of bio-oil and bio-char from pyrolysis of potato peel wastes. Biomass Convers Biorefinery 5:237-246

23. Kumar BGP, Francis RR, Raouf A, Subramanian R, Gupta S, Kannan G, Thirumavalavan K (2020) Torrefied materials derived from waste vegetable biomass. Mater Today Proc 28:852-855. https:// doi.org/10.1016/J.MATPR.2019.12.311

24. Chen S, Meng A, Long Y, Zhou H, Li Q, Zhang Y (2015) TGA pyrolysis and gasification of combustible municipal solid waste. J Energy Inst 88:332-343. https://doi.org/10.1016/J.JOEI.2014. 07.007

25. Mary GS, Sugumaran P, Niveditha S, Ramalakshmi B, Ravichandran P (2016) Seshadri S (2016) Production, characterization and evaluation of biochar from pod (Pisum sativum), leaf (Brassica oleracea) and peel (Citrus sinensis) wastes. Int J Recycl Org Waste Agric 51(5):43-53. https://doi.org/10.1007/S40093-016-0116-8

26. Reddy JP, Rhim J (2018) Extraction and characterization of cellulose microfibers from agricultural wastes of onion and garlic extraction and characterization of cellulose microfibers from. J Nat Fibers 15:1-9. https://doi.org/10.1080/15440478.2014. 945227

27. Maia AAD, de Morais LC (2016) Kinetic parameters of red pepper waste as biomass to solid biofuel. Bioresour Technol 204:157163. https://doi.org/10.1016/j.biortech.2015.12.055

28. Müsellim E, Tahir MH, Ahmad MS, Ceylan S (2018) Thermokinetic and TG/DSC-FTIR study of pea waste biomass pyrolysis. Appl Therm Eng 137:54-61. https://doi.org/10.1016/j.appltherma leng.2018.03.050

29. Sriram A, Swaminathan G (2018) Pyrolysis of Musa balbisiana flower petal using thermogravimetric studies. Bioresour Technol 265:236-246. https://doi.org/10.1016/J.BIORTECH.2018.05.043

30. Choi Y, Jung B, Sung N, Han Y (2015) A study on the drying characteristics from mixture of food waste and sawdust by using microwave / inner-cycle thermal-air drying process. J Mater Cycles Waste Manag 17:359-368. https://doi.org/10.1007/ s10163-014-0248-8

31. Yang H, Yan R, Chen H, Lee DH, Zheng C (2007) Characteristics of hemicellulose, cellulose and lignin pyrolysis. Fuel 86:1781-1788

32. Kim S, Park JK, Chun H-D (1995) Pyrolysis kinetics of scrap tire rubbers. I: using DTG and TGA. J Environ Eng 121:507-514. https://doi.org/10.1061/(ASCE)0733-9372(1995)121:7(507)

33. Leung DY, Wang C (1998) Kinetic study of scrap tyre pyrolysis and combustion. J Anal Appl Pyrol 45:153-169. https://doi.org/ 10.1016/S0165-2370(98)00065-5

34. Leung DYC, Wang CL (1999) Kinetic modeling of scrap tire pyrolysis. Energy Fuels 13:421-427. https://doi.org/10.1021/ EF980124L

35. Senneca O (2007) Kinetics of pyrolysis, combustion and gasification of three biomass fuels. Fuel Process Technol 88:87-97. https://doi.org/10.1016/J.FUPROC.2006.09.002
36. Chen J, Chen K, Tong L (2001) On the pyrolysis kinetics of scrap automotive tires. J Hazard Mater 84:43-55. https://doi.org/10. 1016/S0304-3894(01)00180-7

37. Mui ELK, Lee VKC, Cheung WH, McKay G (2008) Kinetic modeling of waste tire carbonization. Energy Fuels 22:1650-1657. https://doi.org/10.1021/EF700601G

38. Parthasarathy P, Fernandez A, Al-Ansari T, Mackey HR, Rodriguez R, McKay G (2021) Thermal degradation characteristics and gasification kinetics of camel manure using thermogravimetric analysis. J Environ Manage 287:112345. https://doi.org/10.1016/j. jenvman.2021.112345

39. Al-Rumaihi A, Parthasarathy P, Fernandez A, Al-Ansari T, Mackey HR, Rodriguez R, Mazza G, McKay G (2021) Thermal degradation characteristics and kinetic study of camel manure pyrolysis. J Environ Chem Eng 9:106071. https://doi.org/10. 1016/J.JECE.2021.106071

40. Parthasarathy P, Narayanan SK (2014) Determination of kinetic parameters of biomass samples using thermogravimetric analysis. Environ Prog Sustain Energy 33:256-266. https://doi.org/10.1002/EP.11763

41. Parthasarathy P, Narayanan KS, Arockiam L (2013) Study on kinetic parameters of different biomass samples using thermogravimetric analysis. Biomass Bioenerg 58:58-66. https://doi.org/ 10.1016/j.biombioe.2013.08.004

42. Jeguirim M, Elmay Y, Limousy L, Lajili M, Said R (2014) Devolatilization behavior and pyrolysis kinetics of potential Tunisian biomass fuels. Environ Prog Sustain Energy 33:1452-1458. https://doi.org/10.1002/EP.11928

43. Lei Z, Wang S, Fu H, Gao W, Wang B, Zeng J, Xu J (2019) Thermal pyrolysis characteristics and kinetics of hemicellulose isolated from Camellia Oleifera shell. Bioresour Technol 282:228-235. https://doi.org/10.1016/J.BIORTECH.2019.02.131

44. Kumar M, Srivastava N, Upadhyay SN, Mishra PK (2021) Thermal degradation of dry kitchen waste: kinetics and pyrolysis products. Biomass Convers Biorefinery 2021:1-18. https://doi.org/10. 1007/S13399-021-01309-Z

45. Radojević M, Janković B, Stojiljković D, Jovanović V, Čeković I, Manić N (2021) Improved TGA-MS measurements for evolved gas analysis (EGA) during pyrolysis process of various biomass feedstocks. Syngas energy balance determination. Thermochim Acta 699:178912. https://doi.org/10.1016/J.TCA.2021.178912

46. Pinto M, Silva D, Gomes A, Santos R, Couto R, Novais R, Constantino V, Tronto J, Pinto F (2019) Biochar from carrot residues chemically modified with magnesium for removing phosphorus from aqueous solution. J Clean Prod 222:36-46. https://doi.org/ 10.1016/J.JCLEPRO.2019.03.012

47. Nagy G, Wopera A, Koos T (2014) Physical and chemical analysis of canteen wastes for syngas production. Mater Sci Eng 39:59-67

48. Yargiç AS, Yarbay Şahin RZ, Özbay N, Önal E (2015) Assessment of toxic copper(II) biosorption from aqueous solution by chemically-treated tomato waste. J Clean Prod 88:152-159. https://doi. org/10.1016/j.jclepro.2014.05.087

49. Channiwala SA, Parikh PP (2002) A unified correlation for estimating HHV of solid, liquid and gaseous fuels. Fuel 81:1061-1063

50. Giwa AS, Xu H, Wu J, Li Y, Chang F, Zhang X, Jin Z, Huang B, Wang K (2018) Sustainable recycling of residues from the food waste (FW) composting plant via pyrolysis: thermal characterization and kinetic studies. J Clean Prod 180:43-49. https://doi.org/ 10.1016/j.jclepro.2018.01.122

51. Hu S, Jess A, Xu M (2007) Kinetic study of Chinese biomass slow pyrolysis: comparison of different kinetic models. Fuel 86:27782788. https://doi.org/10.1016/j.fuel.2007.02.031

52. Aguiar L, Márquez-Montesinos F, Gonzalo A, Sánchez JL, Arauzo J (2008) Influence of temperature and particle size on the fixed bed pyrolysis of orange peel residues. J Anal Appl Pyrolysis 83:124-130. https://doi.org/10.1016/j.jaap.2008.06.009 
53. Özveren U, Özdoğan ZS (2013) Investigation of the slow pyrolysis kinetics of olive oil pomace using thermo-gravimetric analysis coupled with mass spectrometry. Biomass Bioenerg 58:168-179. https://doi.org/10.1016/j.biombioe.2013.08.011

54. Vamvuka D, Kakaras E, Kastanaki E, Grammelis P (2003) Pyrolysis characteristics and kinetics of biomass residuals mixtures with lignite. Fuel. pp 1949-1960

55. Gupta NK, Prakash P, Kalaichelvi P, Sheeba KN (2016) The effect of temperature and hemicellulose-lignin, cellulose-lignin, and cellulose-hemicellulose on char yield from the slow pyrolysis of rice husk. Energy Sources A Recover Util Environ Eff 38:1428-1434. https://doi.org/10.1080/15567036.2014.941518

56. Font R, Moltó J, Gálvez A, Rey MD (2009) Kinetic study of the pyrolysis and combustion of tomato plant. J Anal Appl Pyrol 85:268-275. https://doi.org/10.1016/j.jaap.2008.11.026

57. Ounas A, Aboulkas A, El harfi K, Bacaoui A, Yaacoubi A (2011) Pyrolysis of olive residue and sugar cane bagasse: nonisothermal thermogravimetric kinetic analysis. Bioresour Technol 102:11234-11238. https://doi.org/10.1016/j.biortech.2011.09.010

58. Di Blasi C (2008) Modeling chemical and physical processes of wood and biomass pyrolysis. Prog Energy Combust Sci 34:47-90

59. Mansaray KG, Ghaly AE (1999) Determination of kinetic parameters of rice husks in oxygen using thermogravimetric analysis. Biomass Bioenerg 17:19-31. https://doi.org/10.1016/S09619534(99)00022-7
60. Kumar A, Wang L, Dzenis YA, Jones DD, Hanna MA (2008) Thermogravimetric characterization of corn stover as gasification and pyrolysis feedstock. Biomass Bioenergy 32:460-467. https:// doi.org/10.1016/j.biombioe.2007.11.004

61. Wu H, Hanna MA, Jones DD (2012) Thermogravimetric characterization of dairy manure as pyrolysis and combustion feedstocks. Waste Manag Res 30:1066-1071. https://doi.org/10.1177/07342 42X12452906

62. Ma M, Bai Y, Song X, Wang J, Su W, Yao M, Yu G (2020) Investigation into the co-pyrolysis behaviors of cow manure and coal blending by TG-MS. Sci Total Environ 728:138828. https://doi. org/10.1016/j.scitotenv.2020.138828

63. Meng A, Zhou H, Qin L, Zhang Y, Li Q (2013) Quantitative and kinetic TG-FTIR investigation on three kinds of biomass pyrolysis. J Anal Appl Pyrolysis 104:28-37. https://doi.org/10.1016/J. JAAP.2013.09.013

64. Özsin G, Pütün AE (2017) Kinetics and evolved gas analysis for pyrolysis of food processing wastes using TGA/MS/FT-IR. Waste Manag 64:315-326. https://doi.org/10.1016/J.WASMAN.2017.03. 020

Publisher's note Springer Nature remains neutral with regard to jurisdictional claims in published maps and institutional affiliations. 